\title{
Addressing an HIV cure in LMIC
}

\author{
Sherazaan D. Ismail ${ }^{1 \dagger}$, Joshua Pankrac ${ }^{2 \dagger}$, Emmanuel Ndashimye ${ }^{2,3}$, Jessica L. Prodger ${ }^{2,4,5}$, \\ Melissa-Rose Abrahams ${ }^{1}$, Jamie F. S. Mann ${ }^{2,7}$, Andrew D. Redd ${ }^{1,5,6}$ and Eric J. Arts ${ }^{2,8^{*}}$
}

\begin{abstract}
HIV-1 persists in infected individuals despite years of antiretroviral therapy (ART), due to the formation of a stable and long-lived latent viral reservoir. Early ART can reduce the latent reservoir and is associated with post-treatment control in people living with HIV (PLWH). However, even in post-treatment controllers, ART cessation after a period of time inevitably results in rebound of plasma viraemia, thus lifelong treatment for viral suppression is indicated. Due to the difficulties of sustained life-long treatment in the millions of PLWH worldwide, a cure is undeniably necessary. This requires an in-depth understanding of reservoir formation and dynamics. Differences exist in treatment guidelines and accessibility to treatment as well as social stigma between low- and-middle income countries (LMICs) and highincome countries. In addition, demographic differences exist in PLWH from different geographical regions such as infecting viral subtype and host genetics, which can contribute to differences in the viral reservoir between different populations. Here, we review topics relevant to HIV-1 cure research in LMICs, with a focus on sub-Saharan Africa, the region of the world bearing the greatest burden of HIV-1. We present a summary of ART in LMICs, highlighting challenges that may be experienced in implementing a HIV-1 cure therapeutic. Furthermore, we discuss current research on the HIV-1 latent reservoir in different populations, highlighting research in LMIC and gaps in the research that may facilitate a global cure. Finally, we discuss current experimental cure strategies in the context of their potential application in LMICs.
\end{abstract}

Keywords: HIV-1, Cure, Reservoir, Low-and-middle income countries, LMICs

\section{Introduction}

The advent of antiretroviral therapy (ART) has converted the HIV-associated death sentence into a lifelong, manageable illness for those with adequate access. However, for many low-and middle-income countries (LMICs), access to sustained ART for the full population is challenging due to a variety of socio-economic factors. This is especially true in regions with the greatest infection burden, Eastern and Southern Africa, which account for more than half of all the people living with HIV-1 (PLWH). While, globally, more PLWH are aware

\footnotetext{
*Correspondence: earts@uwo.ca

†Sherazaan D. Ismail and Joshua Pankrac contributed equally

${ }^{2}$ Department of Microbiology and Immunology, Schulich School

of Medicine and Dentistry, University of Western Ontario, London, ON N6A5C1, Canada

Full list of author information is available at the end of the article
}

of their seropositive status $(\sim 80 \%)$ and are accessing treatment $(\sim 67 \%)$ [1], this still falls short of the original 90-90-90 goal set forth by the United Nations for awareness of status, accessing treatment, and viral suppression, respectively. In addition, due to the development of drug-resistant strains, the ART failure rate for PLWH on first-line regimens is $5 \%$ per year, necessitating constant development of new treatments over time. Lifelong ART also imposes a substantial financial burden on alreadyconstrained public health systems; as PLWH continue to live longer, the overall cost of ART has risen to an estimated 26.2B USD globally in 2020 [1] and could reach 40B USD if goals for 2030 are going to be met. Even a long-term remission of HIV-1 disease [undetectable viral load (VL)] in the absence of ART, as opposed to a sterilizing cure, would save the world from millions of future deaths and trillions of USD in drug and health care costs.

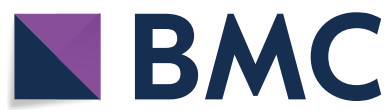

(c) The Author(s) 2021. This article is licensed under a Creative Commons Attribution 4.0 International License, which permits use, sharing, adaptation, distribution and reproduction in any medium or format, as long as you give appropriate credit to the original author(s) and the source, provide a link to the Creative Commons licence, and indicate if changes were made. The images or other third party material in this article are included in the article's Creative Commons licence, unless indicated otherwise in a credit line to the material. If material is not included in the article's Creative Commons licence and your intended use is not permitted by statutory regulation or exceeds the permitted use, you will need to obtain permission directly from the copyright holder. To view a copy of this licence, visit http://creativecommons.org/licenses/by/4.0/. The Creative Commons Public Domain Dedication waiver (http://creativecommons.org/publicdomain/zero/1.0/) applies to the data made available in this article, unless otherwise stated in a credit line to the data. 
Finally, even with full viral suppression there is still a high risk for other long-term morbidities, including an increased risk of heart, bone, and kidney disease [2, 3], and PLWH can be impacted socially, financially, and psychologically due to HIV stigma and discrimination. Thus, there is an urgent need for a cure for HIV-1.

The benefits of an HIV-1 cure to PLWH and the publichealth system in LMICs are clear and undeniable (Fig. 1). However, as discussed below, most cure approaches in preclinical development, or even those tested in clinical trials, may be financially prohibitive and impractical to administer in the near future in many LMICs, especially in sub-Saharan Africa. Currently, even just participation in clinical trials testing cure modalities requires frequent VL monitoring, reservoir quantification (currently developed only for subtype B), and full viral suppression, all readily available in high income countries (HICs) [4], but not in LMICs. Universally, the major barrier for HIV-1 cure is the existence of a long-lived latent reservoir consisting of stably integrated proviruses that persist in the host within various cell types and anatomical locations. Proviruses within the reservoir capable of reactivation and re-establishing plasma viraemia upon ART cessation persist despite years of suppressive ART [5-7]. PLWH exhibit differences in infecting viral subtype, immune responses to HIV-1, and disease progression,

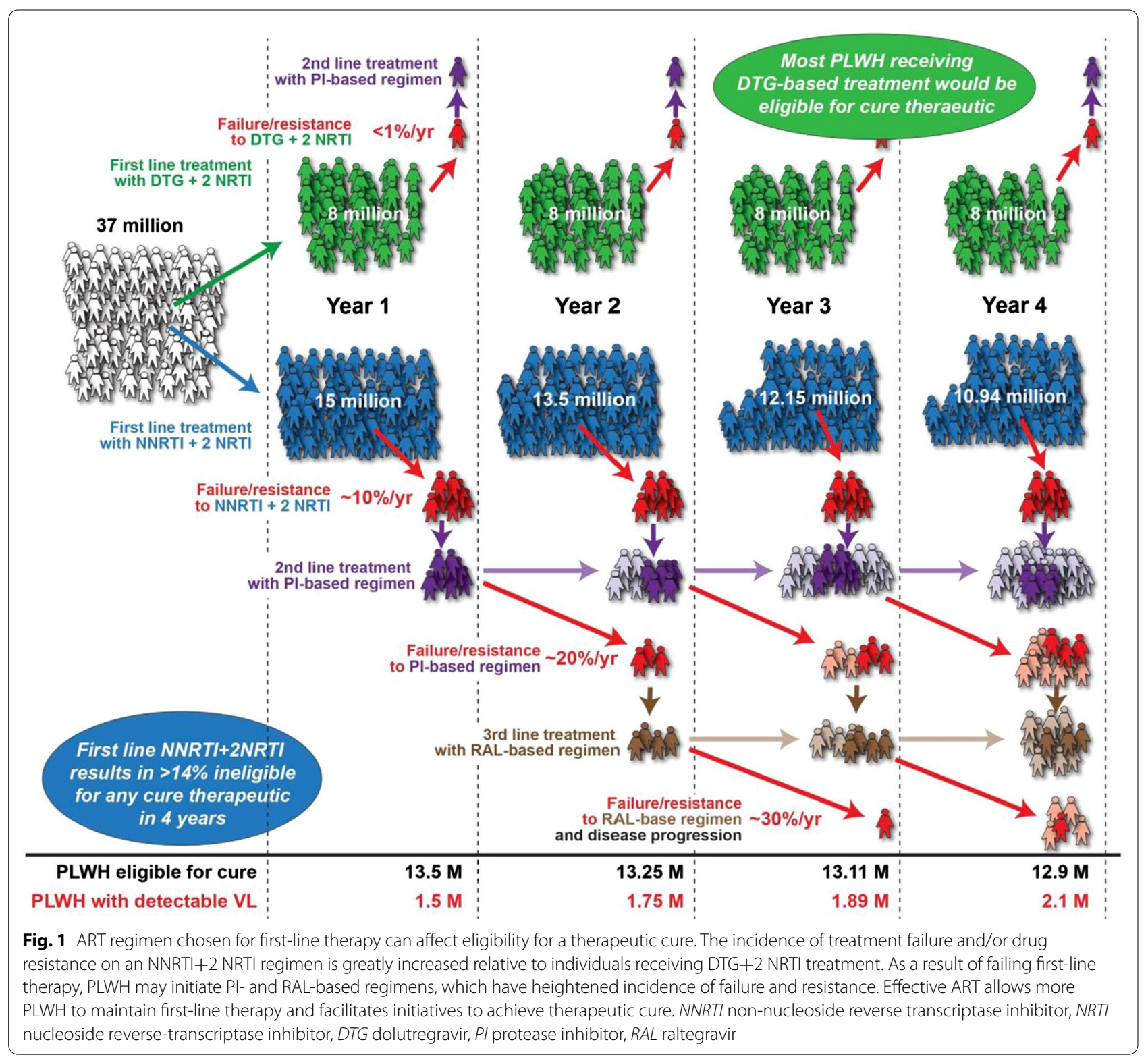


notably between individuals in LMICs vs. HICs, as well as between sexes [8-10]. Similarly, differences exist in the size, composition, and turnover in the reservoir between PLWH.

In this review, we discuss the viral and host cellular phenomena contributing to HIV-1 proviral latency establishment and persistence. With this knowledge, we will discuss the most relevant strategies for intervention and cure, highlighting scientific gaps that may influence generalizability of findings to LMICs.

\section{The current state of ART in LMICs}

Early ART has been shown to limit seeding of the HIV-1 reservoir and is associated with post-treatment control. By diminishing the amount of immune activation, $\mathrm{CD} 4^{+}$ $\mathrm{T}$ cell depletion and VLs in untreated infection, what results is fewer target cells for HIV-1 infection, preservation of the immune response [11-13], and a lower burden of viraemia over time. Thus, effective HIV-1 treatment in LMICs is necessary to implement a cure therapeutic. This may require use of more potent ART as a functional cure strategy during early stage of HIV infection. However, challenges of limited early HIV diagnosis, and access to potent ART regimens in LMICs need to be addressed. Successful distribution of generic DTG in LMICs through the Medicines Patent Pool (MPP) program [14] coupled with high rate of adherence by patients in LMICs [15] are good indicators that a cure therapeutic in LMIC setting can be achieved. Furthermore, optimization of a cure approach that will be effective in the millions of PLWH who initiated treatment during chronic infection is imperative. Therefore, to establish the potential utility of cure strategies in LMICs, it is essential to understand differences in ART treatment rollout among diverse global populations.

Global access to ART has increased tremendously. By end of 2019, over 26 million people had access to ART of which 17.9 million (69\%) were PLWH in sub-Saharan Africa [16]. Despite this staggering number, the proportion of PLWH on ART in sub-Saharan Africa is still well below the UN target of $90 \%$, and this is also true for South America (62\%) and Asia and the Pacific (60\%). Historically, first-line regimens in sub-Saharan Africa have included two nucleoside reverse transcriptase inhibitors (NRTIs) and one non-nucleoside reverse transcriptase inhibitor (NNRTI), commonly efavirenz (EFV) or nevirapine [17]. However, due to the combination of frequent drug supply/access issues in LMICs resulting in treatment interruptions [18] and the low genetic barrier to HIV-1 drug resistance mutations associated with NRTI + NNRTI regimens [19], $10-15 \%$ of patients who start ART still fail within one year, and $70-80 \%$ of people with virological failure develop acquired drug resistance
[20]. In Kampala, Uganda, failure of first-line treatment continues to occur at an annual rate of 9\% [21]. This statistic of treatment failure and drug resistance is rarely mentioned in discussion of the 90-90-90 goals by various global enterprises championing these goals.

For patients failing first-line therapy, the guidelines in most sub-Saharan African countries [and supported by the Global Fund and the U.S. President's Emergency Plan for AIDS Relief (PEPFAR)] calls for a second-line ART of an NRTI + protease inhibitor (PI) and, subsequent to the failure of second-line, a third-line four-drug therapy of the NNRTI etravirine, the PI darunavir, and an integrase inhibitor with any suitable NRTI [22-24]. The choice of "salvage" treatment regimens in LMICs is limited due to lack of access to CCR 5 antagonists, fusion inhibitors, and second-generation PIs and NNRTIs- agents with a higher barrier to HIV-1 drug resistance employed when patients fail treatment with first-generation PIs and NNRTIs. Limited ART options may exacerbate problems facing ART programs in sub-Saharan Africa, including adherence on ART, which directly translates to increased mortality. Indeed, a recent modelling study shows that 6 months of ART disruption for $50 \%$ of people would result in 296,000 more AIDS-related deaths in sub-Saharan Africa over one year [18]. Furthermore, frequent use of suboptimal NRTI + NNRTIs regimens has led to a $>10 \%$ prevalence of strains resistant to either NNRTIs or NRTIs in treatment-naïve PLWH [25]. Without pre-screening for drug resistance prior to initiation of first-line ART, treatment failure is likely to increase over time. High rates of treatment interruption and/or first-line failure present a huge barrier to cure therapeutic testing in sub-Saharan Africa, as all protocols to date have required participants to be fully virally suppressed. However, this need not be a barrier; provided there is stable drug supply, effective distribution to clinics/pharmacies, and ease of access to PLWH, adherence and success of first-line treatment is outstanding and often better in LMICs than HICs.

Despite the sombre predictions described above, the roll out of a dolutegravir (DTG)-based regimen $(\mathrm{TDF}+3 \mathrm{TC} / \mathrm{FTC}+\mathrm{DTG})$ as a preferred first-line treatment at the end of 2017 has slowly improved the treatment success rates in all LMICs. Current estimates indicate that between 5 and 10 million PLWH in subSaharan African countries and other LMICs are receiving a DTG-based regimen [26]. In treatment naïve individuals, DTG-based treatment regimens are extremely well tolerated with minimal adverse events promoting high treatment adherence. Treatment failure and resistance to DTG is extremely rare in clinical studies to date due in part to high genetic barrier for resistance [27] to these second-generation integrase inhibitors (INSTIs). If the combination of DTG, bictegravir and the long-acting 
cabotegravir were available in dual or triple drug formulations, especially as one-pill-a-day, treatment success would improve dramatically in LMICs and thus provide a population of PLWH in LMICs that could be treated with an affordable and practical cure therapeutic.

Treatment outcome studies in Africa and other LMICs are heavily affected by different sociodemographic factors between countries, regions, ethnic groups, tribes, and religions [28-31]. As previously described in several cross sectional and longitudinal analyses on treatment adherence and HIV-1 drug resistance in Uganda and other sub-Saharan African countries, one of the greatest contributors to treatment failure is poor access to care/ARVs and intermittent ARV shortages, even more so than differential sociodemographic factors. Across sub-Saharan Africa and in LMICs during COVID-19 pandemic, ARV shortages, disruption in shipments, and reduced foreign aid will likely contribute to ART failure by orders of magnitude higher than the impact of HIV-1 types/subtypes, human genetics, and sociodemographic factors.

In a specific area where the HIV-infected population are impoverished and share similar sociodemographic conditions, religion, ethnicity, etc., the co-circulating HIV-1 subtypes and/or CRFs could impact the effectiveness of any proposed cure therapeutic. Like all antiretroviral drugs developed to date, preclinical development and early phase human clinical trials of cure therapeutics have all been based on the ability to inhibit HIV-1 subtype B isolates, i.e., the HIV-1 strains that predominate in HICs. While ARTs have similar inhibitory effectiveness regardless HIV-1 subtype in terms of initial response to treatment [32-35], the effect of subtype on the emergence of drug resistance is not yet fully understood. For instance, despite similar in vitro susceptibility of subtype $\mathrm{C}$ and B strain-derived HIV-1 integrase enzymes to the currently-approved INSTIs, differential levels of drug resistance were observed between HIV-1 subtype B versus $C$ viruses in cell culture assays, likely resulting from differential mutational pathways being favored between different subtypes [36]. Additionally, in vivo development of drug DTG resistance occurs at a slower rate among PLWH infected with subtype B compared to subtypes A/G and C [37]. Drug resistance to NRTIs and PIs has been shown to occur more frequent in subtype B compared to subtype C ( $26 \%$ vs. $8 \%$ for NRTIs, and 54 vs. $23 \%$ for PI's, respectively) [38]. In Uganda, drug resistance and treatment failure is more prevalent in subtype $\mathrm{D}$ compared to A or C-infected patients (Fig. 2) [39]. These differences could be explained by variability of HIV-1 genes at the amino acid level between different subtypes and higher entropy scores observed at sites where drug resistance mutations emerge [40].
Differences in disease progression exist depending on infecting viral subtype [41, 42]. In Uganda and Zimbabwe, HIV-1 subtype D is associated with faster disease progression [43-46] but lower transmission rates than subtype A [45, 47]. Furthermore, subtype C viruses were linked with rapid disease progression in South African women [48]. The difference in disease progression between HIV-1 subtypes is likely multifactorial [33-35, $39,46]$. However, functional differences between HIV-1 subtypes may influence reservoir formation, kinetics, and the efficacy of a cure therapeutic. "HIV-1 acquisition risk (discussed extensively in [49]) and disease progression is known to differ between the sexes. Women exhibit a faster progression to AIDS-defining illness than men, even at matched viral loads [50] and have higher levels of inflammation and immune activation $[51,52]$ than men. In addition, women are the most affected by HIV-1 in sub-Saharan Africa and disproportionately contribute to the global burden of disease [49]. Thus, it is imperative that we tailor cure therapeutics to address an HIV-1 cure in this population."

Predicting the effectiveness of cure strategies against different HIV-1 subtypes will be complicated. Some cure therapeutics aim to activate transcription by targeting specific HIV-1 sequences, which will likely vary between the subtypes. Patterns of recombination sites in the host genome differ by subtype [53]. Integration site may also be relevant in determining HIV-1 persistence and vary by subtype. New data shows that, compared to in vitroderived HIV-1 integration sites, in vivo-derived sites are significantly more enriched in transcriptionally silent regions of the genome, which has relevance to reactivation of latent proviruses. With regard to subtype, integration sites from PLWH infected with HIV-1 subtype $\mathrm{A}, \mathrm{C}$ or D viruses exhibited different preferences for specific genomic features and were more enriched in transcriptionally active regions of the genome compared to subtype B virus [53]. Theoretically, any type of transcriptional activation strategy to induce latency reversal may require greater potency in a subtype $B$ setting compared to subtype A, C and D infected individuals.

\section{Measuring and characterizing the latent viral reservoir}

The evaluation of reservoir stability and the efficacy of clinical interventions and/or changes in the reservoir after "drug holidays" or other periods of ART cessation necessitates a reliable method of quantifying the frequency of latently-infected cells that is cost and time effective [54]. This method would ideally not only enable the determination of reservoir size, but also characterize the proviral landscape to monitor qualitative changes in the reservoir. Several methods have been developed to quantify the reservoir to date. Each method measures 


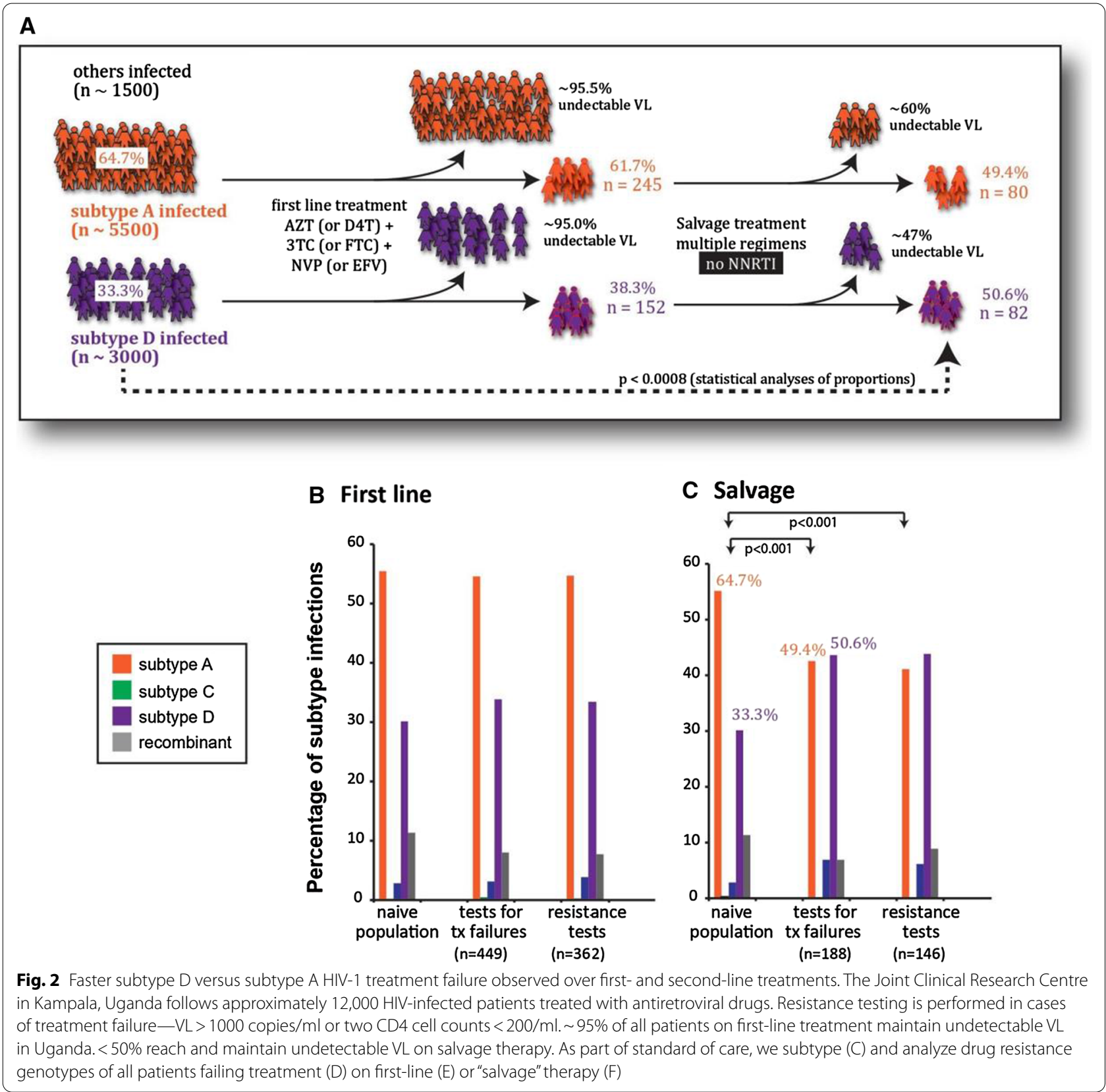

different aspects of the reservoir and each has caveats on the conclusions that can be drawn. Table 1 provides a summary of current sizing methods and assay examples. However, only the detection of HIV-1 DNA by qRT-PCR could currently be widely implemented in most LMICs and even this methodology would be difficult to apply in some small hospitals and more rural clinics in sub-Saharan Africa. However, this method significantly overestimates the theoretical "true" replication-competent reservoir, which is the frequency of cells harbouring genetically intact proviruses that are capable of recrudescence in the absence of suppressive ART, because resting $\mathrm{CD}^{+}{ }^{+} \mathrm{T}$ cells harbour $\sim$ tenfold more defective than intact proviruses [55-58]. This distinction is especially important when assessing efficacy of a potential cure therapeutic, as differences in decay between intact and defective proviruses have been reported, with a slow but significant decline in intact proviruses over time on ART and little to no decline in defective proviruses [59].

In contrast, the quantitative viral outgrowth assay (QVOA) [5, 60, 61] is currently the gold standard for 


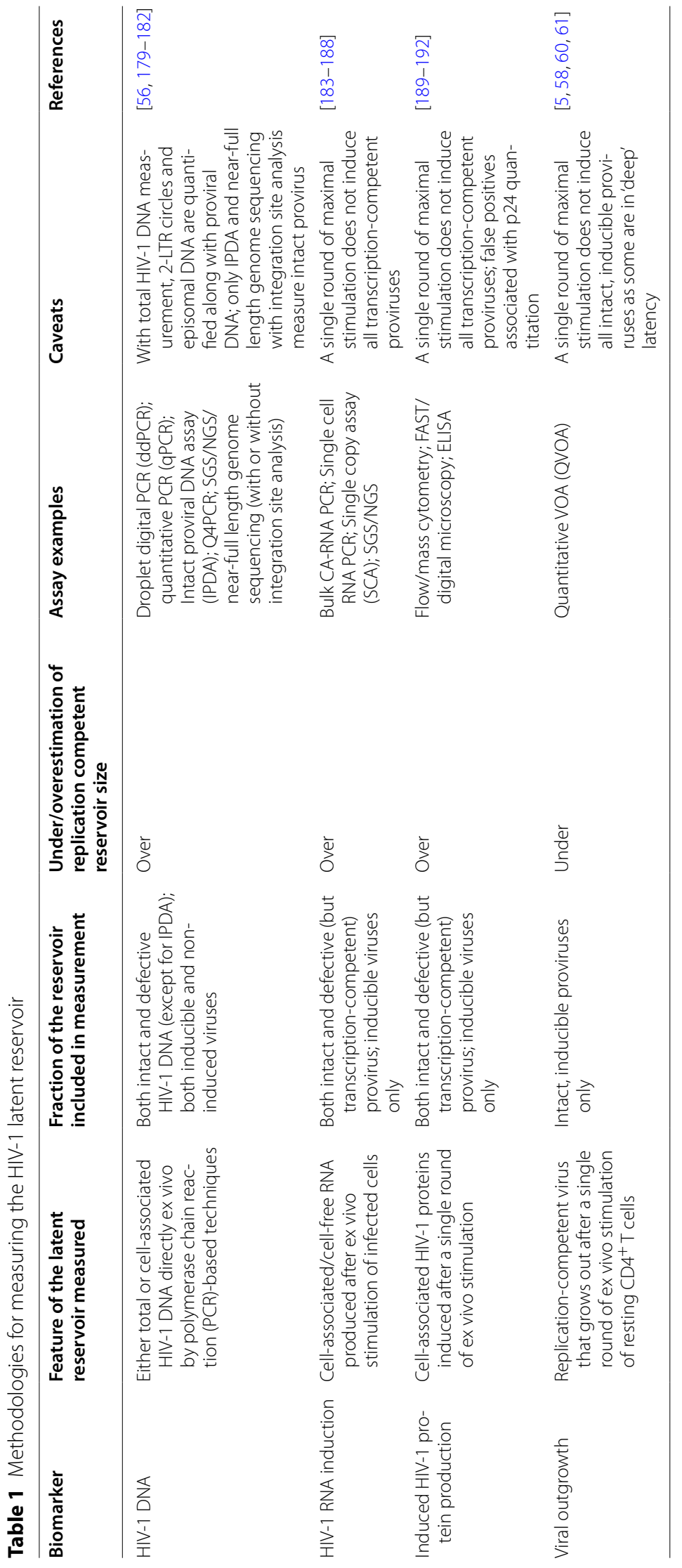


measuring the frequency of cells harbouring replication competent provirus, but underestimates the true reservoir as this assay relies on ex vivo reactivation of latently infected cells, and it has been demonstrated that in vitro reactivation methods are not $100 \%$ efficient and their efficacy may vary between populations of PLWH [58]. Additionally, this assay is resource-intensive and requires additional biosafety containment for the culture of live HIV-1. As such, the QVOA may only be practical in LMIC sites performing clinical trials of cure therapeutics and this assay would likely not be adopted as standardof-care assay to monitor the effectiveness of cure therapeutics upon approval.

Using QVOA, the size of the latent reservoir has been estimated to be one infected cell per million resting $\mathrm{CD}^{+} \mathrm{T}$ cells in PLWH in North American cohorts $[62,63]$. Historically in sub-Saharan Africa, treatment has most commonly been initiated in chronic infection, leading to an expectation that the barrier to a cure would to be greater due to lack of restriction of reservoir size through early treatment (as highlighted in the section to follow). However, we have previously reported that PLWH in Uganda (who initiated ART during chronic infection) have reduced replication competent reservoir size (three-fold lower by QVOA) compared to North Americans [8], and that Ugandan females have additionally smaller replication-competent reservoirs than males. Interestingly, despite lower QVOA outgrowth, HIV-1 DNA levels were similar between males and females [9]. Other studies report lower intracellular HIV-1 DNA in females compared to males $[64,65]$, highlighting important differences that may need to be considered when assessing latency reversal strategies. These studies in Uganda are two of only a handful of published studies of replication-competent reservoir size in Africans, highlighting the need for more studies in diverse LMIC settings to examine if other differences in populations exist that may help us to better understand the latent reservoir. Given that close to two thirds of women bear the burden of disease in some LMIC [66], such differences between the sexes need to be established if a global cure is to be achieved. Furthermore, only one study exists showing the association between early ART initiation and HIV-1 DNA levels in children, highlighting a paucity of cure studies in children living with HIV-1 in LMICs.

HIV-1 reservoir establishment, heterogeneity, and kinetics Studying the mechanisms that dictate reservoir establishment is challenging. Specifically, cells isolated from an infected individual have already entered into a latent state and therefore can only provide a pseudo-measure of this process. The long-lived reservoir in PLWH displays significant heterogeneity in sequence composition, clonality, genomic integration sites, rates of decay and the proportion of replication-competent to defective proviruses present in cells.

Infected resting memory $\mathrm{CD} 4^{+} \mathrm{T}$ cells are the most well-characterised of HIV-1 reservoir cells, are highly stable, with a half-life $\left(\mathrm{t}_{1 / 2}\right)$ of $\sim 44$ months, and can theoretically persist for the lifetime of an affected individual $[6,62,63]$. Resting $C D 4^{+} \mathrm{T}$ cells exhibit decreased expression of $\mathrm{T}$ cell activation markers, lower RNA content, and are not cycling [67], resulting in reduced HIV-1 transcription and favouring latency. Activated effector $\mathrm{CD}^{+}{ }^{+} \mathrm{T}$ cells represent a primary target for HIV-1 infection due to their high permissiveness and metabolic state relative to resting cellular subsets. Many of these cells, as well as other non-HIV-specific $\mathrm{CD} 4^{+} \mathrm{T}$ cells, are productively infected with HIV-1 and produce viral products, which are then detectable by host immune mechanisms. Such cells are primed for elimination and are unlikely to contribute to persistence in vivo $[68,69]$. Rather, latency establishment likely occurs as cells that are transitioning towards a long-lived memory phenotype [70]. Alternatively, proviral integration can occur directly in resting CD4 T cells [71, 72]. However, despite their high abundance in the body, resting cells are relatively resistant to infection, due to low expression of the HIV-1 co-receptor CCR5, limited dNTP availability, and an increase in heterochromatic structures $[73,74]$.

\section{Differences in integration sites, viral diversity, and decay in the HIV-1 reservoir}

Following transmission, HIV-1 variants diversify rapidly [75-79], reaching a plateau in chronic infection [80]. However, not all variants are equally likely to be represented in the long-lived viral reservoir [10]. Rather, variants present at the time of ART initiation are significantly over-represented, measured by both HIV-1 DNA [81, 82] and QVOA [10]. Our South African study (where subtype $C$ predominates) evaluating cells from nine women showed that 17 to $100 \%$ (average: $71 \%$ ) of the replication-competent viruses in the reservoir after five years of suppressive treatment were genetically similar to the viral variants circulating in the patient's plasma the year immediately preceding ART initiation [10]. In comparison, the percentage of viruses seeded into the long-lived reservoir within the first year from the estimated time of infection ranged from 0 to $17 \%$ (average: $4 \%$ ). Similarly, a study in Kenyan women on ART for up to 5 years showed that 59 to $99 \%$ (median: $86 \%$; measured by gag sequences) of HIV-1 DNA during ART comprised of sequences present in plasma within 2 years of ART initiation [82]. These findings indicate that the long-lived reservoir may not be formed continuously at the same rate. 
Instead, it is possible that ART initiation establishes an environment favouring latency. Work by Jones et al. $[83,84]$ highlights the persistence of viral variants from earlier time-points in infection, even if in smaller proportion. The mechanism of persistence of these variants or factors affecting their longevity in the reservoir are still to be elucidated.

In early treated individuals infected with subtype $C$ viruses, the reservoir was found to have a majority of proviral sequences intact, a low frequency of hypermutated genomes, and a paucity of truncated genomes which are found commonly in chronically-infected, untreated individuals [85]. While this scenario may not represent the majority of PLWH in LMICs due to late initiation of ART, the future of cure in these settings will benefit from more longitudinal studies characterizing reservoir heterogeneity.

\section{Cellular and tissue reservoirs}

One area with currently no reported characterization in LMIC studies to our knowledge, is that of cellular and tissue reservoir sites. Specific lineages of memory $\mathrm{CD}^{+}{ }^{+} \mathrm{T}$ cells, the major cellular reservoir of HIV-1, can persist for an individual's lifetime. Their memory differentiation status, as well as their functional polarization dictates longevity, anatomical location, and likelihood of being a stable reservoir. Central memory $\left(\mathrm{T}_{\mathrm{CM}}\right)$ cells are most likely to harbour provirus, followed by transitional memory $\left(\mathrm{T}_{\mathrm{TM}}\right)$ and effector memory $\left(\mathrm{T}_{\mathrm{EM}}\right) \mathrm{T}$ cells [86-88]. A recent study showed that intact proviral DNA copies in each of these subsets varied greatly between individuals [57], but the distribution of relative abundances were similar between subsets and there were no differences in the contribution of each subset to the total pool of intact proviral copies. Less abundant subsets, such as stem cell memory $\mathrm{T}$ cells $\left(\mathrm{T}_{\mathrm{SCM}}\right)$, also contribute to the reservoir, although only substantially in some individuals $[89,90]$. Early treatment appears to increase the contribution of $\mathrm{T}_{\mathrm{SCM}}$ to the total $\mathrm{CD}^{+}{ }^{+}$reservoir, reducing per-cell HIV-1 DNA levels in $\mathrm{T}_{\mathrm{EM}}$ and $\mathrm{T}_{\mathrm{TD}}$ (terminally differentiated) subsets [91]. The contribution of each subset to the reservoir over time on suppressive ART is difficult to study due to the dynamic nature of cell differentiation where a cell can evolve from one subset into others. Thus, the contribution of each subset to rebound virus remains an understudied topic. However, studies have showed that viral rebound likely does not have a singular source of cell type or anatomical location [92-94]. The proportion and number of $\mathrm{T}$ cell subsets during disease and following treatment is poorly understood between viral subtypes and may also differ between early- and late- treated populations. This merits further investigation in the context of the HIV-1 reservoir in LMICs vs. $\mathrm{HICs}$.

\section{Clonality and homeostatic proliferation}

The proliferation of $\mathrm{CD}^{+}{ }^{+} \mathrm{T}$ cells brought about by proliferation from homeostatic regulation and in response to antigen stimulation [95] results in large pools of clonal sequences in vivo [92, 96-102], comprising both defective and intact proviruses. In our South African study, we reported between 0 and $47 \%$ (by sequence identity) of outgrowth viruses form PBMCs were clonal in nature [10]. Furthermore, another small study found that clonal sequences were rare over the first year of ART in early treated PLWH, providing insights into the difference in reservoir composition between early- and late-treated individuals infected with subtype $C$ viruses [85]. Replication-competent clonal populations have been found to be distributed across different $T$ cell memory subsets [57, 92, 103], indicating that infected cells differentiate and proliferate during ART unabated by the immune system [103, 104]. In addition to memory differentiation, differences in functional polarization may influence reservoir size. One study found that functional polarization may lead to preferential clonal expansion of replication-competent HIV-1 in Th ${ }_{1}$ cells [105]. Furthermore, these clonal populations are found in different tissues and can contribute to plasma viral rebound when treatment ceases [92, 94]. A caveat with some of these studies is that frequently only a small region of the HIV-1 genome is sequenced, so that it cannot be definitively known if cells with identical sequences in that region are the result of integration by a pool of homogenous viruses, or due to homeostatic proliferation of infected cells, the latter defining a true clonal population. Integration site analysis is required to distinguish between these two possibilities, as the likelihood that integration will occur multiple times in the same location in the human genome is negligible [106]. Nevertheless, it is clear that clonal populations of HIV-1 contribute markedly to reservoir maintenance. Antigenic stimulation and immune modulation are likely different in LMICs vs. HICs, and further studies are needed to assess the contribution of clonal expansion and latency in different cellular subsets in other populations in LMICs.

\section{Viral factors contributing to HIV-1 persistence}

The role of infecting subtype in reservoir formation, size and maintenance is greatly understudied. Particularly in LMIC where the predominant infecting subtypes differ from the most studied cohorts (predominated by subtype $B$ infections), this may result in significant geographical differences in the latent viral reservoir. The viral promoter element of HIV-1, the long terminal repeat (LTR), 
has been reported to impact latency [107], with 'latency potential' (defined as the ratio of latently infected cells to actively infected) differing between subtype-specific LTR genotypes in vitro [108]. In subtype $C$ viruses, increased levels of transcriptional activity resulted in more rapid silencing of the viral promoter due to negative feedback, and was associated with a greater number of NF- $\mathrm{kB}$ binding sites within the LTR [109]. Furthermore, the AP1genotype (a binding motif in the LTR) has been shown to confer greater latency potential (i.e. reduced proportion of cells that lack transcription of HIV-1 genes) to subtype A and C viruses compared to subtype B [110]. Conversely, another study showed no differences in initial latency potential between subtypes with the exception of subtype $\mathrm{AE}$ in primary $\mathrm{T}$ cells [111].

The HIV-1 transcriptional switch protein, Tat, is heavily implicated in the establishment and persistence of latent provirus. Tat regulates transcriptional elongation via RNA polymerase II (RNAP II) recruitment in the viral 5' LTR. For viral transcription to occur, Tat must bind the trans-activating response (TAR) hairpin present on the viral transcript. In a study by Razooky et al., Tatmediated feedback was able to induce proviral reactivity in the absence of cellular stimulation [112]. In fact, in the absence of multiply spliced RNA encoding tat/rev, the feedback loop was disrupted and led to non-productive infection [113]. Due to the heavy implication of HIV-1 Tat on transcriptional status, this protein is critical to many therapeutic strategies being utilized today, highlighting the importance of characterizing tat variants in the reservoir. Subtype C Tat (TatC) has been shown to have a higher transcriptional activity in $\mathrm{T}$ cell lines than Tat from subtypes B (TatB) and E [114]. Furthermore, genetic variations in TAR can impact the ability of Tat to facilitate viral transcription [115]. Studies identified intra-subtype $C$ variation in the TAR element as well as Tat that correspond to key functional sites that affect Tat binding and Tat-induced transcriptional activity, respectively [116-118]; including evidence of positive selection in primary infection [117]. In addition to mediating transcription, the viral protein Tat is also responsible for RNA silencing suppressor activity (RSS) in infected cells [119-122]. RSS serves to attenuate translation of HIV-1 transcripts, determining viral load set-point and favouring latency. TatB has been shown to have more potent RSS activity than that of TatC viruses, however, a greater range of RSS activity was observed among TatCs [123].

The HIV-1 accessory protein Nef is an element of interest as a reservoir determinant. Nef facilitates the pathogenesis of HIV-1 by interfering with host protein trafficking [124]. Furthermore, sequestration of major histocompatibility complex-1 (MHC-I) by Nef precludes antigen presentation by infected cells and evasion of the host CTL response as a result $[125,126]$. In a recent study, the strain-specific ability of Nef to downregulate MHC-I in vitro was associated with in vivo reservoir size [127]. Furthermore, in a multivariable analysis adjusting for multiple clinical factors, HIV-1 DNA levels were found to be higher in individuals infected with subtype $B$ compared to those infected with non-B subtypes (CRF_01 AE and G), and this higher abundance of cells harbouring HIV-1 DNA was attributable to the superior Nef function of subtype B viruses. However, this study included only men who initiated treatment in acute/ early infection and were on treatment for less than a year [127]. Given that Nef function has been shown to differ across subtypes, with subtype $\mathrm{C}$ exhibiting reduced $\mathrm{Nef}$ function compared to other subtypes [128], it will be beneficial to assess Nef function in the context of other HIV-1 subtypes, females, and PLWH who initiated treatment during chronic infection, to determine the generalizability of these findings to LMIC.

\section{Clinical and immunological correlates of the HIV-1 reservoir}

The most well-characterized clinical measure that correlates with reservoir size is pre-ART viral load (VL). Several studies show that pre-ART VL setpoint, or even just the VL the time of ART initiation, correlates positively with HIV-1 DNA $[13,127]$ and QVOA estimates of reservoir size $[8,9]$, which is consistent with studies showing that early ART restricts reservoir size (both replicationcompetent and HIV-1 DNA) [91, 129-131]. In ARTtreated patients, CD4 counts over time have also been shown to predict replication-competent reservoir size in PLWH who initiated treatment in acute infection [132], and several studies have identified the extent of CD4 depletion as shaping the HIV-1 DNA proviral load [133, 134], with nadir CD4 count and CD4:CD8 ratio shown to be strong negative correlates of reservoir size. Furthermore, time on ART has also been shown to correlate negatively with replication-competent reservoir size [9].

Events soon after the establishment of infection impact disease progression, and there is mounting evidence that this may be the case for characteristics of the latent reservoir. Immune activation and inflammation play an important role in the disease progression of HIV-1 [135, 136]. Immune activation is very strongly correlated with set-point $\mathrm{VL}$, and predicts progression to AIDS-defining illness more robustly than VL $[13,135,137]$. Early initiation of ART not only reduces the cumulative viral burden before ART, preserves CD4 ${ }^{+} \mathrm{T}$ cells, and maintains CD4:CD8 ratios, but also reduces $\mathrm{T}$ cell activation and inflammation [11-13]. T cell activation may increase the pool of target cells available to sustain HIV-1 replication, but also augments antigen-driven clearance of infected 
cells and thus increases $\mathrm{T}$ cell turnover. Following ART initiation, many measures of immune activation decline rapidly, but this does not occur equally in all individuals, and residual inflammation is a strong predictor of non-AIDS mortality in the context of successful ART [138]. Understanding upstream contributors to $\mathrm{T}$ cell activation, such as cytokine expression throughout both treated and untreated infection, may shed light on subsequent HIV-1 reservoir dynamics over time. IL-10, and sTNFRII concentrations were positively associated with levels of total HIV-1 DNA in peripheral blood mononuclear cells (PBMCs) after 96 weeks of treatment [13], while MIP-3 $\beta$ showed a trend towards a correlation.

Since immune activation and inflammation are known to differ between the sexes, detailed studies into the immune correlates of reservoir size in males and females are needed. We recently reported a difference in the immune correlates between males and females in PLWH in Uganda [9]. While in males the frequency of PD- $1^{+}$ $\mathrm{CD} 4^{+} \mathrm{T}$ cells and $\mathrm{IL}-2^{+} \mathrm{CD} 8^{+} \mathrm{T}$ cells were positive and negative correlates of replication-competent reservoir size, respectively, only $\mathrm{TNF}^{+} \mathrm{CD} 8^{+} \mathrm{T}$ cells was found to have a positive association with replication-competent reservoir size in females. The lack of a positive association between PD-1 expression and reservoir size in women may be of particular concern, as this association, well-established in men, has led to the development of PD-1 agonists as latency reversal agents. The efficacy of this therapy, and other immune-based cure therapeutics, should be carefully tested in both sexes.

Several studies have suggested that inflammation and immune activation are different in African cohorts [139-143]. High levels of genital inflammation have been observed in a well-characterized cohort of South African females [144] and high levels of inflammation during early infection in this cohort correlated with VL set-point and, to a lesser degree, disease progression (as measured by CD4 depletion). Few studies have addressed ongoing immune activation in the context of Africans receiving ART. Understanding of the impact of immune activation on viral reservoir dynamics at multiple stages of HIV-1 infection, particularly in cohorts where ART was initiated in chronic infection, is imperative to formulating cure strategies in LMIC.

Finally, the paucity of reservoir studies in different geographical settings also means that critical information on reservoir establishment and dynamics in the face of co-infections is overlooked. Moreover, an in-depth discussion of co-infections and the HIV- 1 reservoir is precluded by the absence of studies on the topic. Coinfections have been shown to increase pathogenesis and HIV-1 viral loads, increase immune activation, and inflammation. Thus, our discussion on how increased or decreased viral loads, immune activation, and inflammation impacts reservoir size would extend to the more general effect of co-infections. Effective treatment of co-infections (excluding hepatitis $\mathrm{B}$ and $\mathrm{C}$ ) results in a reduction of plasma viraemia in ART naïve PLWH [1]. As there remains fundamental questions on the timing of viral reservoir seeding prior to ART initiation [10, 145-148], the effects of longer term (e.g. TB) or periodic/ sporadic (e.g. malaria or HSV) co-infections on the viral reservoir may depend on the timing of these event(s) during acute and chronic disease and the timing of ART initiation. Furthermore, infections that lower the barrier to HIV-1 acquisition such as bacterial vaginosis and other sexually transmitted infections, resulting in an increased HIV-1 risk or a higher multiplicity of infection, may influence HIV-1 reservoir size or composition. This topic has been reviewed extensively elsewhere [2], including a detailed summary of knowledge gaps with regards to specific co-infections such as Mycobacterium tuberculosis, Hepatitis B and C, helminth infections, and other STIs. LMICs have a higher burden of co-infections and thus, latent reservoir studies in this context are of great importance for cure strategies in the future.

\section{Strategies for HIV-1 eradication and cure}

In the context of HIV-1, researchers often refer to cure as either 'functional' or 'sterilizing'. In either instance, a cure would allow for PLWH to interrupt ART without experiencing viral rebound. For a functional cure, HIV-1 is durably controlled in the absence of ART, while remaining, in some form, within the body. Alternatively, a sterilizing cure aims to remove all traces of HIV-1, including provirus, from PLWH. The primary strategies being investigated for HIV-1 cure are mentioned below and will highlight the practicality of implementation of these strategies/therapeutics in LMICs based on ease of potential clinical use, cost, and availability.

\section{Hematopoietic stem cell transplant}

To date, an apparently sterilizing cure has been achieved in two individuals $[149,150]$. These individuals received a homozygous CCR5 $\Delta 32$ hematopoietic stem cell transplant following immune ablation. The CCR5 $\Delta 32$ mutation renders cells impervious to strains of HIV-1 that use CCR5 as a co-receptor. These; the ablation eliminates a substantial portion of the cells harbouring replication competent provirus, and the transplanted CCR5 $\triangle 32$ that reconstitute the immune system are resistant to HIV-1 infection. While these cases of sterilizing cure offer proof that a cure is possible, this procedure is associated with high mortality and would not be appropriate for an otherwise healthy person living with HIV. For those with treatment access, ART provides a lower risk alternative 
with relatively fewer co-morbidities, while excluding the possibility of treatment-associated death. Additionally, the high procedure-associated cost (i.e., approaching several hundred thousand dollars per patient for treatment, hospitalization, and follow-up monitoring) limit scalability and global rollout. Aside from the risk to the patients, this approach will never be widely adopted even in HICs based on cost alone.

\section{Shock-and-kill}

The 'shock-and-kill' strategy aims to induce transcriptional reactivation of the replication-competent proviral reservoir, and has been recently reviewed by Kim et al. [151]. The intention is that induced cells will produce viral products that are recognizable by host immune mechanisms, prompting their clearance by cytotoxic immune mechanisms. During this process, an individual would maintain daily ART to prevent de novo infection of bystander cells by virus produced by reactivated cells. Since post-ART rebound occurs at a frequency of approximately once a week, a substantial proportion of the reservoir must be cleared for this approach to be feasible [152]. For instance, a 1,000-fold reduction in the replication competent reservoir is theoretically required to achieve an average remission of 20 years [153]. Such modeling reveals the innate challenge of developing a functional 'shock-and-kill' therapeutic, while also indicating that it is theoretically possible with the correct approach.

Latency-reversing agents (LRAs) comprise small molecules and biologics designed to induce transcriptional reactivation of virally infected cells. Amongst the most investigated are histone deacetylase inhibitors (HDACi), which function through direct inhibition of the HDAC enzyme. HDACi can induce highly variable latency reversal in cell lines engineered with latent HIV-1 provirus [154] but fail to induce appreciable HIV-1 from cells isolated from PLWH on stable ART [155-157]. HDACi activate a low level of transcription, but undetectable HIV-1 protein synthesis, which is necessary for immune recognition and elimination of these latently infected cells. They have been utilized with low level, daily dosing in phase I/II clinical trials, but have failed to reduce the latent HIV-1 pool [145]. Increased dosage may provide better latency reversal, but HDACi are not selective for latent, integrated HIV-1 proviral DNA and would result in general transcription upregulation of host genes.

In lieu of epigenetic manipulation, some approaches target cellular activation pathways. Protein kinase C (PKC) agonists, for example, induce global $\mathrm{T}$ cell signalling and transcription factor recruitment [158]. Similarly, toll-like receptors (TLRs) that recognize RNA viruses, such as TLR $3 / 7 / 8$, can mediate $\mathrm{T}$ cell activation and downstream induction of latent proviral expression, while also enhancing cytolytic activity [159]. One example is the TLR-7 agonist, GS-9620 (Vesatolimod; Gilead), which became a strong candidate after pre-clinical data showed clearance of hepatitis B in several models of infection [160, 161]. In clinical trials, GS-9620 could potently induce expression of interferon-stimulated genes (ISG), leading researchers to investigate the agonist's potential as a latency-reversing agent for HIV-1. A subsequent ex vivo study revealed that TLR-7 agonists could promote HIV-associated RNA production by $1.5-$ twofold [162]. In a recent Phase Ib study, GS-9620 was well-tolerated at doses sufficient to induce ISG expression $(>4 \mathrm{mg}$ ) [163], providing feasibility for use in future regimens.

Interestingly, several studies have indicated that optimal latency reversal could require stimulation through the T cell receptor (TCR) [164, 165]. Signalling through the TCR, best demonstrated by the use of PMA/Ionomycin or anti-CD3/anti-CD28 antibodies, results in an intracellular cascade for multi-kinase activation, chromatin remodelling and transcription factor induction necessary for immune activation of memory and naïve $\mathrm{T}$ cell subset [166]. Interestingly, the same activation cascade is required for productive HIV-1 replication in activated $\mathrm{T}$ cells, and reactivation of latent provirus is more potent after stimulation with HIV-1 antigen, as opposed to non-HIV-specific antigen, which may be due to the preferential infection of HIV-specific T cells [167]. Upon primary HIV-1 infection, antigens consisting of HIV-1 virus particles and proteins are transported to primary and secondary lymphoid tissues/organs by antigen presenting cells. These APCs will ultimately present HIV-1 antigens on MHC class II to CD4 ${ }^{+} \mathrm{T}$ cells with TCR specific to these HIV-1 antigens, leading to activated $\mathrm{CD} 4^{+}$ $\mathrm{T}$ cells, which are now susceptible to HIV-1 infection and replication [168]. We hypothesize that this cycle of HIV-1 antigen presentation and activation of HIV-specific $\mathrm{T}$ cells leads to a skewing of the antigen-specificity of latently infected cells towards HIV-1 antigens [169]. This hypothesis is supported by the observation that most variants in the reservoir arose from strains circulating immediately prior to ART initiation [10, 81, 82]: once ART is initiated and HIV-1 antigens are cleared HIV-specific T cells will revert to a resting state en masse. The use of HIV-1 antigens as an immunogen could specifically reactivate and eliminate this substantial portion of the reservoir [169], We have recently developed heterogenous virus-like particle (VLP) derived from the quasi-species of five HIV-1 infected patients [169, 170]. This VLP formulation contains all the HIV-1 proteins and is morphologically identical to wild type HIV-1 but lacks genomic RNA and has additional mutations to 
ensure it is not replication-competent and can be tested as a cure therapeutic [170]. Heterogenous HIV-1 VLPs have so far out-performed all other LRAs at induction of the latent $\mathrm{HIV}-1$ pool from $\mathrm{CD} 4^{+} \mathrm{T}$ cells isolated from patients on stable ART. The level of latent HIV-1 induction by these VLPs is comparable to PMA/ionomycin but the VLPs, unlike PMA/ionomycin, target only a fraction of $\mathrm{CD}^{+} \mathrm{T}$ cells for activation and therefore is unlikely to create generalize and toxic immune activation. These findings suggest that VLPs may result in targeted activation of a sizeable proportion of the latent pool. However, for this therapeutic to be useful in LMIC, the effect of subtype congruency between VLP and patient must be ascertained. Additionally, while activation of the latent HIV-1 pool in response to VLP has been observed using cells form patients treated during both acute/early [169] and chronic infection, it must be ascertained if the reservoir of individuals treated during chronic infection is as heavily skewed towards HIV-specific T cells. Individuals who initiated ART soon after infection will have been exposed to fewer non-HIV antigens while viremic, but only a minority of PLWH in LMIC initiated treatment during acute infection. Aside from these remaining uncertainties, compared to the use of small molecules lacking a specific targeting mechanism, the use of VLPs is safe, effective, and is an inexpensive cure therapeutic that could potentially be widely used around the world.

Many of these small molecule or even peptide-based inhibitors/agonists would be a suitable cure therapeutic for testing and potential roll-out in LMICs. Importantly, such strategies would greatly benefit from longitudinal follow-ups to ensure viremia is suppressed in the absence of ART. Currently, their cost remains prohibitive, but with relaxation of the agreement on trade-related aspects of intellectual property rights (TRIPS) agreement/patent regulations for greater drug access for LMIC markets, it is possible that investment by the Global Fund, PEPFAR, and various other foundations, would be offset by the reduction in the burden of ART, the concern of ART drug resistance, and the prevention of new infections.

\section{Block-and-lock}

The 'block-and-lock' approach aims to provide a functional cure for HIV-1 through the suppression of transcriptional activity. One way to achieve this is by altering methylation and acetylation status. For a block-and-lock approach, this will typically involve a combination of hyper-methylation and/or hypo-acetylation. Furthermore, many strategies are utilizing small interfering (si) RNA to induce epigenetic changes at sites of transcriptional relevance, such as the HIV-1 NF-kB promoter site [171-173]. An alternative approach is blocking the HIV-1 accessory protein, Tat, which is involved in the recruitment of RNA polymerase II. Blocking its function might greatly limit transcriptional output. DidehydroCortistatin A (dCA) is one small molecule capable of engaging with HIV-1 TAR RNA-the binding domain of Tat [174] - and dCA treatment renders cells resistant to the effects of LRAs [175]. Another study proposed the use of "naked" cyclic Tat peptidomimetics that have rapid cellular uptake, that bind HIV-1 TAR RNA with high affinity, and inhibit Tat transactivation/mRNA transcription as well as reverse transcription [176, 177].

For a block-and-lock strategy to be curative, virtually all replication competent provirus would require durable, drug-mediated post-translational modification. This means that, even if a small proportion remains unmodified, the chance of productive re-infection exists. However, studies have shown that reducing the size of the replication competent reservoir can prolong the time to viral recrudescence [153]. This would arguably be true of epigenetic silencing as well. Therefore, the lock-andblock strategy likely reduces risk of re-infection shortterm, but will invariably lead to rebound unless complete, sustained reservoir silencing is achieved.

The block-and-lock approach is uniquely positioned from a therapeutic perspective. Since the goal here is not the removal of the viral genomes but rather their suppression, blocking agents could potentially function on multiple distinct cellular reservoirs. Block-and-lock inhibitors are also easier to design, test, and possibly utilize for treatment. However, long acting formulations are necessary for these inhibitors to be considered as a cure therapeutic, as opposed to a form of ART. Long-acting ART will provide a benefit for those PLWH who have issues with adherence (adolescents, etc.), and was found to be more acceptable than oral ART in the context of pre-exposure prophylaxis [178], but may not replace oral ART completely in the very near future. One of the drawbacks of long-acting ART administration is having more frequent clinic visits: once a month or every two months as opposed to biannually. In addition, well-resourced settings may be able to handle the operational challenges associated with switching from oral to injectable medications: potentially more staff required on site, more frequent VL testing to ensure viral suppression between visits, increased challenges with regards to ensuring all visits occur timeously, storage and transport of injectables/infusions. In terms of LMICs, this may ease the burden on PLWH who have access to these resources in urban and suburban settings but may not work well in rural settings unless distribution of these interventions can be decentralized (i.e. administered outside of a clinical setting). More research is needed into whether these treatments can be administered by non-medical personnel or whether self-administration of these drugs is 
feasible. Despite the challenges, intermittent administration of block-and-lock therapeutics could reduce pill burden and alleviate ART-associated co-morbidities. As with all potential therapeutics, global investment and robust organizational initiatives are mandatory for proper rollout and maintenance in LMICs, assuming a clinically successful 'block-and-lock' strategy is realized.

\section{Broadly neutralizing antibodies as a cure therapeutic}

The discovery of monoclonal antibodies capable of potent neutralization of a wide range of HIV-1 isolates, termed broadly neutralizing antibodies (bNAbs), has provided new avenues for functional cure research. In-human trials (passive immunization) have been conducted with several bNAbs and they have been shown to be tolerable and safe, even at high doses and when administered repeatedly in both HIV-1 uninfected $[4,5]$ and infected adults [6, 7]. Monoclonal bNAb therapy did not result in decrease in residual plasma viraemia [8], HIV-1 DNA/ RNA $[8,9]$ or outgrowth viruses (demonstrated with VRC01) [8] but did result in a delay in viral rebound after analytical treatment interruption (ATI), demonstrated with VRC01 [10, 11], 3BNC117 [12], and UB-241 [13], although results were highly variable across trials (ranging from 4 to 16 weeks median time to rebound). Combination bNAb therapy has also shown promise, with the benefit of a decreased likelihood of developing resistance to multiple antibodies [7]. Trials testing sequential administration of $2 \mathrm{G} 12,2 \mathrm{~F} 5$, and $4 \mathrm{E} 10$ resulted in 8-10week delay in viral rebound upon ATI $[14,15]$. Administration of 3BNC117 and 10-1074 in combination during ATI resulted in maintained viral suppression for a median of 21 weeks in participants who had antibody sensitive viral reservoirs [6].

A phase I clinical trial is ongoing in South African women (CAPRISA 012), testing CAP256V2LS, a potent bNAb isolated from a subtype $C$ infected individual capable, alone and in combination with VRC07-523LS and PGT121 for use in pre-exposure prophylaxis [16]. However, this trial could pave the way for investigation into CAP256V2LS (likely in combination) as a functional cure in Africans. Finally, the first studies in non-human primates showed efficacy of bNAbs produced in vivo through the administration of adeno-associated viruses encoding bNAbs [17]. Although host-elicited immune responses limited effectiveness of the treatment [18], one macaque was functionally cured. While this approach is still in development and needs refining before in-human trials, it is a proof of concept for the role bNAbs in a functional cure strategy. A disadvantage associated with bNAb therapy in resource-limited settings is the requirement for resistance screening both before administration of therapy to ensure antibody sensitivity of viruses, and during therapy to monitor antibody escape. Similar to long-acting ART, these drawbacks significantly limit the scalability of bNAbs as a cure therapeutic.

\section{Summary}

The development of a HIV-1 cure has been a major initiative for the global scientific community and a dominant target for drug development. Having over 40 million people on lifelong ART is not a sustainable global strategy and with increasing circulation of drug resistant HIV-1, new infections may not be prevented by ART alone. An affordable and effective cure therapeutic that could be rapidly deployed during first ART is a necessary goal for the elimination of HIV-1 from the human population. However, HIV-1 cure research has been largely focused on the eventual application to PLWH in HICs, and potential therapeutics are not being designed or tested with the majority of PLWH in mind. Until the rollout of second-generation INSTIs for treatment, the rate of treatment failure and resistance was already preventing the testing of cure therapeutics in as much as $10-20 \%$ of the $20+$ million PLWH receiving ART in LMICs. Considering HIV cure strategies/therapeutics currently under investigation, cost and feasibility present challenges to implementation in LMICs. This is complicated by the lack of studies characterising reservoir size, composition and determinants of HIV persistence in these key populations. We identified research topics that would aid in the development and implementation of a global cure therapeutic: (i) reservoir sizing studies in LMICs and the development of a cheap, meaningful and standardized assay to assess reservoir size changes in PLWH; (ii) identifying subtype differences in various HIV-1 proteins/elements linked to pathogenesis including Tat, the LTR, and Nef, along with their interplay in reservoir establishment and kinetics; (iii) differences in clonality and cellular distribution of the reservoir particularly in chronicallytreated individuals. Finally, resources need to be made available for the study of cure therapeutics in the setting of LMICs, since this will address the largest burden of HIV-1 infection globally.

\section{Abbreviations}

PLWH: People living with HIV-1; ART: Antiretroviral therapy; LMICs: Lowand- middle-income countries; HICs: High income countries; HIV-1: Human immunodeficiency virus type 1; VL(s): Viral load(s); PEPFAR: U.S. President's Emergency Plan for AIDS Relief; NRTI (s): Nucleoside reserves transcriptase inhibitor(s); NNRTI(s): Non-nucleoside reserves transcriptase inhibitor(s); EFV: Efavirenz; AZT: Zidovudine; TDF: Tenofovir disoproxil fumarate; 3TC: Lamivudine; PI(s): Protease inhibitors; DTV: Dolutegravir; FTC: Emtricitabine; QVOA: Quantitative viral outgrowth assay; LTR: Long terminal repeat; TatB: HIV-1 subtype B Tat protein; TatC: HIV-1 subtype C Tat protein; MHC-1: Major histocompatibility complex $1 ; T_{\mathrm{CM}}$ : Central memory $T_{\text {cells; }} \mathrm{T}_{\mathrm{TM}}$ : Transitional memory $T$ cells; $T_{E M}$ : Effector memory $T$ cells; $T_{S C M}$ : Stem cell-like memory $T$ cells; $T_{T D}$ : Terminally differentiated T cells; PBMCs: Peripheral blood mononuclear cells; $T_{h}$ : Helper T cell; LRAs: Latency-reversing agents; HDACi: Histone deacetylase 
inhibitors; HMTi: Histone methyltransferase inhibitors; DNMTi: DNA methyltransferase inhibitors; TLR: Toll-like receptor; TCR (s): T cell receptor(s); VLP: Virus-like particle; dCA: Didehydro-cortistatin A.

\section{Acknowledgements}

We would like to thank Stephen Barr, PhD (Western University, CA), for contributing pre-published data for this manuscript. SDI was supported by the National Research Foundation, the Poliomyelitis Research Foundation, and the university of Cape Town, South Africa. The funders have no role in preparation of this article. SDI was supported by the National Research Foundation, the Poliomyelitis Research Foundation, and the university of Cape Town, South Africa. The funders have no role in preparation of this article.

\section{Authors' contributions}

SDI, JP and EN wrote the manuscript with contributions from all authors. All authors read and approved the final manuscript.

\section{Funding}

This work was supported in part by the Division of Intramural Research, NIAID, $\mathrm{NIH}$.

\section{Availability of data and materials \\ Not applicable.}

\section{Declarations}

\section{Ethics approval and consent to participate}

Not applicable.

\section{Consent for publication}

Not applicable.

\section{Competing interests}

The authors declare that they have no competing interests.

\begin{abstract}
Author details
${ }^{1}$ Division of Medical Virology, Department of Pathology, Institute of Infectious Disease and Molecular Medicine, University of Cape Town, Cape Town 7925, South Africa. ${ }^{2}$ Department of Microbiology and Immunology, Schulich School of Medicine and Dentistry, University of Western Ontario, London, ON N6A5C1, Canada. ${ }^{3}$ Center for AIDS Research Uganda Laboratories, Joint Clinical Research Centre, Kampala, Uganda. ${ }^{4}$ Department of Epidemiology and Biostatistics, Schulich School of Medicine and Dentistry, University of Western Ontario, London, ON N6A 5C1, Canada. ${ }^{5}$ Division of Infectious Diseases, Department of Medicine, Johns Hopkins University School of Medicine, Baltimore, MD, USA. ${ }^{6}$ Laboratory of Immunoregulation, Division of Intramural Research, National Institute of Allergy and Infectious Diseases, NIH, Bethesda, MD, USA. 'Bristol Veterinary School, University of Bristol, Langford House, Langford, Bristol BS40 5DU, UK. ${ }^{8}$ Division of Infectious Diseases, Department of Medicine, Case Western Reserve University, Cleveland, OH 44106, USA.
\end{abstract}

Received: 7 May 2021 Accepted: 19 July 2021

Published online: 03 August 2021

\section{References}

1. UNAIDS. Fact sheet-global AIDS update 2019. UNAIDS. 2019. https:// www.unaids.org/en/resources/fact-sheet. Accessed 13 Apr 2021.

2. Freiberg MS, Chang C-CH, Kuller LH, Skanderson M, Lowy E, Kraemer $\mathrm{KL}$, et al. HIV infection and the risk of acute myocardial infarction. JAMA Intern Med. 2013;173:614. https://doi.org/10.1001/jamainternmed.2013. 3728.

3. Brown TT, Qaqish RB. Antiretroviral therapy and the prevalence of osteopenia and osteoporosis: a meta-analytic review. AIDS. 2006;20:2165-74. https://doi.org/10.1097/QAD.0b013e32801022eb.

4. Saag MS, Gandhi RT, Hoy JF, Landovitz RJ, Thompson MA, Sax PE, et al. Antiretroviral drugs for treatment and prevention of HIV infection in adults. JAMA. 2020;324:1651. https://doi.org/10.1001/jama.2020.17025.
5. Finzi D. Identification of a reservoir for HIV-1 in patients on highly active antiretroviral therapy. Science. 1997;278:1295-300. https://doi, org/10.1126/science.278.5341.1295.

6. Finzi D, Blankson J, Siliciano JD, Margolick JB, Chadwick K, Pierson $\mathrm{T}$, et al. Latent infection of $\mathrm{CD}^{+} \mathrm{T}$ cells provides a mechanism for lifelong persistence of HIV-1, even in patients on effective combination therapy. Nat Med. 1999;5:512-7.

7. Chun T-W, Stuyver L, Mizell SB, Ehler LA, Mican JAM, Baseler M, et al. Presence of an inducible HIV-1 latent reservoir during highly active antiretroviral therapy. Proc Natl Acad Sci. 1997;94:13193-7. https:// doi.org/10.1073/pnas.94.24.13193.

8. Prodger JL, Lai J, Reynolds SJ, Keruly JC, Moore RD, Kasule J, et al. Reduced frequency of cells latently infected with replicationcompetent human immunodeficiency virus-1 in virally suppressed individuals living in Rakai, Uganda. Clin Infect Dis. 2017;65:1308-15. https://doi.org/10.1093/cid/cix478.

9. Prodger JL, Capoferri AA, Yu K, Lai J, Reynolds SJ, Kasule J, et al. Reduced HIV-1 latent reservoir outgrowth and distinct immune correlates among women in Rakai, Uganda. JCI Insight. 2020;5: e139287. https://doi.org/10.1172/jci.insight.139287.

10. Abrahams M-R, Joseph SB, Garrett N, Tyers L, Moeser M, Archin N, et al. The replication-competent HIV-1 latent reservoir is primarily established near the time of therapy initiation. Sci Transl Med. 2019;11: eaaw5589. https://doi.org/10.1126/scitranslmed.aaw5589.

11. Ndhlovu ZM, Kazer SW, Nkosi T, Ogunshola F, Muema DM, Anmole $\mathrm{G}$, et al. Augmentation of HIV-specific T cell function by immediate treatment of hyperacute HIV-1 infection. Sci TransI Med. 2019;11: eaau0528. https://doi.org/10.1126/scitranslmed.aau0528.

12. Rajasuriar R, Wright E, Lewin SR. Impact of antiretroviral therapy (ART) timing on chronic immune activation/inflammation and end-organ damage. Curr Opin HIV AIDS. 2015;10:35-42. https://doi.org/10.1097/ $\mathrm{COH} .0000000000000118$

13. Teigler JE, Leyre L, Chomont N, Slike B, Jian N, Eller MA, et al. Distinct biomarker signatures in HIV acute infection associate with viral dynamics and reservoir size. JCl insight. 2018;3:1-8.

14. Algeria gains inclusion to ViiV Healthcare and MPP adult licence enabling greater access to dolutegravir-based HIV treatments-MPP. 2020. https://medicinespatentpool.org/news-publications-post/alger ia-gains-access-to-mpp-dtg-adult-licence\#_ftnref1. Accessed 11 Jun 2021.

15. Mills EJ, Nachega JB, Buchan I, Orbinski J, Attaran A, Singh S, et al. Adherence to antiretroviral therapy in sub-Saharan Africa and North America. JAMA. 2006;296:679. https://doi.org/10.1001/jama.296.6. 679.

16. UNAIDS. Global HIV \& AIDS statistics - 2020 fact sheet | UNAIDS. 2020. https://www.unaids.org/en/resources/fact-sheet. Accessed 13 Apr 2021.

17. HIV/AIDS Programme. Antiretroviral therapy for HIV infection in adults and adolescents: recommendations for a public health approach. 2006. https://apps.who.int/iris/handle/10665/43554. Accessed 13 Apr 2021.

18. Jewell BL, Mudimu E, Stover J, ten Brink D, Phillips AN, Smith JA, et al. Potential effects of disruption to HIV programmes in sub-Saharan Africa caused by COVID-19: results from multiple mathematical models. Lancet HIV. 2020;7:e629-40. https://doi.org/10.1016/S2352-3018(20) 30211-3.

19. WHO. HIV drug resistance report 2019.

20. Clutter DS, Jordan MR, Bertagnolio S, Shafer RW. HIV-1 drug resistance and resistance testing. Infect Genet Evol. 2016;46:292-307. https://doi. org/10.1016/j.meegid.2016.08.031.

21. Kaleebu P, Kirungi W, Watera C, Asio J, Lyagoba F, Lutalo T, et al. Virological response and antiretroviral drug resistance emerging during antiretroviral therapy at three treatment centers in Uganda. PLoS ONE. 2015;10: e0145536. https://doi.org/10.1371/journal.pone.0145536.

22. World Health Organization. Consolidated guidelines on the use of antiretroviral drugs for treating and preventing HIV infection. https:// www.who.int/hiv/pub/guidelines/arv2013/arvs2013upplement_march 2014/en/. Accessed 12 Apr 2021.

23. WHO. Consolidated guidelines on the use of antiretroviral drugs for treating and preventing HIV infection. 2016. https://www.who.int/hiv/ pub/arv/arv-2016/en/. Accessed 12 Apr 2021. 
24. Edessa D, Sisay M, Asefa F. Second-line HIV treatment failure in subSaharan Africa: a systematic review and meta-analysis. PLOS ONE. 2019;14: e0220159. https://doi.org/10.1371/journal.pone.0220159.

25. WHO. Tackling HIV drug resistance: Trends, guidelines, and global action. 2017. https://www.who.int/hiv/pub/drugresistance/tacklinghiv-drug-resistance/en/. Accessed 13 Apr 2021.

26. HIV Market Report: The state of HIV treatment, testing, and prevention in low- and middle-income countries. Clinton Health Access Initiative. 2020. https://3cdmh310dov3470e6x160esb-wpengine.netdna-ssl. com/wp-content/uploads/2020/09/2020-CHAI-HIV-Market-Report.pdf. Accessed 23 Apr 2021

27. Boffito M, Waters L, Cahn P, Paredes R, Koteff J, Van Wyk J, et al. Perspectives on the barrier to resistance for dolutegravir + lamivudine, a two-drug antiretroviral therapy for HIV-1 infection. AIDS Res Hum Retroviruses. 2020;36:13-8. https://doi.org/10.1089/aid.2019.0171.

28. Wasti SP, Simkhada P, Randall J, Freeman JV, van Teijlingen E. Factors influencing adherence to antiretroviral treatment in Nepal: a mixedmethods study. PLoS ONE. 2012;7: e35547. https://doi.org/10.1371/ journal.pone.0035547.

29. Anderson K, Muloiwa R, Davies M-A. Long-term outcomes in perinatally HIV-infected adolescents and young adults on antiretroviral therapy: a review of South African and global literature. African J AIDS Res. 2020;19:1-12. https://doi.org/10.2989/16085906.2019.1676802.

30. Ahoua L, Guenther G, Pinoges L, Anguzu P, Chaix M-L, Le Tiec C, et al. Risk factors for virological failure and subtherapeutic antiretroviral drug concentrations in HIV-positive adults treated in rural northwestern Uganda. BMC Infect Dis. 2009;9:81. https://doi.org/10.1186/ 1471-2334-9-81.

31. Posse M, Meheus F, Van Asten H, Van Der Ven A, Baltussen R. Barriers to access to antiretroviral treatment in developing countries: a review. Trop Med Int Heal. 2008;13:904-13. https://doi.org/10.1111/j.1365-3156. 2008.02091.x.

32. Geretti AM, Harrison L, Green H, Sabin C, Hill T, Fearnhill E, et al. Effect of HIV-1 subtype on virologic and immunologic response to starting highly active antiretroviral therapy. Clin Infect Dis. 2009;48:1296-305. https://doi.org/10.1086/598502

33. Bocket L, Cheret A, Deuffic-Burban S, Choisy P, Gerard Y, de la Tribonnière $X$, et al. Impact of human immunodeficiency virus type 1 subtype on first-line antiretroviral therapy effectiveness. Antivir Ther. 2005;10:247-54.

34. Easterbrook PJ, Smith M, Mullen J, O'Shea S, Chrystie I, Ruiter A, et al. Impact of HIV-1 viral subtype on disease progression and response to antiretroviral therapy. J Int AIDS Soc. 2010;13:4-4. https://doi.org/10. 1186/1758-2652-13-4

35. Poon AFY, Ndashimye E, Avino M, Gibson R, Kityo C, Kyeyune F, et al. First-line HIV treatment failures in non-B subtypes and recombinants: a cross-sectional analysis of multiple populations in Uganda. AIDS Res Ther. 2019;16(1):1-10.

36. Bar-Magen T, Donahue DA, McDonough El, Kuhl BD, Faltenbacher VH $\mathrm{Xu}$ H, et al. HIV-1 subtype B and C integrase enzymes exhibit differential patterns of resistance to integrase inhibitors in biochemical assays. AIDS. 2010;24:2171-9. https://doi.org/10.1097/QAD.0b013e32833cf265.

37. Quashie PK, Mesplede T, Han Y-S, Oliveira M, Singhroy DN, Fujiwara T, et al. Characterization of the R263K mutation in HIV-1 integrase that confers low-level resistance to the second-generation integrase strand transfer inhibitor dolutegravir. J Virol. 2012;86:2696-705. https://doi.org/ 10.1128/JVI.06591-11.

38. Grossman Z, Vardinon N, Chemtob D, Alkan ML, Bentwich Z, Burke M, et al. Genotypic variation of HIV-1 reverse transcriptase and protease: comparative analysis of clade C and clade B. AIDS. 2001;15:1453-60. https://doi.org/10.1097/00002030-200108170-00001.

39. Kyeyune F, Nankya I, Metha S, Akao J, Ndashimye E, Tebit DM, et al. Treatment failure and drug resistance is more frequent in HIV-1 subtype $D$ versus subtype A-infected Ugandans over a 10-year study period. AIDS. 2013;27:1899-909. https://doi.org/10.1097/QAD.0b013e3283 610 ec7.

40. Theys K, Libin PJK, Van Laethem K, Abecasis AB. An evolutionary modelbased approach to quantify the genetic barrier to drug resistance in fast-evolving viruses and its application to HIV-1 subtypes and integrase inhibitors. Antimicrob Agents Chemother. 2019;63:1-12. https:// doi.org/10.1128/AAC.00539-19.
41. Touloumi G, Pantazis N, Pillay D, Paraskevis D, Chaix M-L, Bucher HC, et al. Impact of HIV-1 subtype on cd4 count at HIV seroconversion, rate of decline, and viral load set point in European seroconverter cohorts. Clin Infect Dis. 2013;56:888-97. https://doi.org/10.1093/cid/cis1000.

42. Novitsky V, Wang R, Bussmann H, Lockman S, Baum M, Shapiro R, et al. HIV-1 subtype C-infected individuals maintaining high viral load as potential targets for the "test-and-treat" approach to reduce HIV transmission. PLoS ONE. 2010;5: e10148. https://doi.org/10.1371/journ al.pone.0010148.

43. Kiwanuka N, Laeyendecker O, Robb M, Kigozi G, Arroyo M, McCutchan F, et al. Effect of human immunodeficiency virus type 1 (HIV-1) subtype on disease progression in persons from Rakai, Uganda, with incident HIV-1 infection. J Infect Dis. 2008;197:707-13. https://doi.org/10.1086/ 527416.

44. Kaleebu P, French N, Mahe C, Yirrell D, Watera C, Lyagoba F, et al. Effect of human immunodeficiency virus (HIV) type 1 envelope subtypes $A$ and $D$ on disease progression in a large cohort of HIV-1-positive persons in Uganda. J Infect Dis. 2002;185:1244-50. https://doi.org/10. 1086/340130.

45. Kaleebu P, Nankya IL, Yirrell DL, Shafer LA, Kyosiimire-Lugemwa J, Lule DB, et al. Relation between chemokine receptor use, disease stage, and HIV-1 subtypes A and D. JAIDS J Acquir Immune Defic Syndr. 2007;45:28-33. https://doi.org/10.1097/QAl.0b013e3180385aa0.

46. Venner CM, Nankya I, Kyeyune F, Demers K, Kwok C, Chen PL, et al. Infecting HIV-1 subtype predicts disease progression in women of subSaharan Africa. EBioMedicine. 2016;13:305-14.

47. Kiwanuka N, Laeyendecker O, Quinn TC, Wawer MJ, Shepherd J, Robb M, et al. HIV-1 subtypes and differences in heterosexual HIV transmission among HIV-discordant couples in Rakai, Uganda. AIDS. 2009;23:2479-84. https://doi.org/10.1097/QAD.0b013e328330cc08.

48. Mlisana K, Werner L, Garrett NJ, McKinnon LR, van Loggerenberg F, Passmore J-AS, et al. Rapid disease progression in HIV-1 subtype C-infected South African Women. Clin Infect Dis. 2014;59:1322-31. https://doi.org/ 10.1093/cid/ciu573.

49. Abdool Karim Q, Havlir D, Phanuphak N. Putting women in the centre of the global HIV response is key to achieving epidemic control! J Int AIDS SOc. 2020;23:23-5.

50. Farzadegan H, Hoover DR, Astemborski J, Lyles CM, Margolick JB, Markham RB, et al. Sex differences in HIV-1 viral load and progression to AIDS. Lancet. 1998;352:1510-4. https://doi.org/10.1016/S0140-6736(98) 02372-1.

51. Sankaran-Walters S, Macal M, Grishina I, Nagy L, Goulart L, Coolidge $K$, et al. Sex differences matter in the gut: effect on mucosal immune activation and inflammation. Biol Sex Differ. 2013;4:10. https://doi.org/ 10.1186/2042-6410-4-10.

52. Klein SL, Flanagan KL. Sex differences in immune responses. Nat Rev Immunol. 2016;16:626-38. https://doi.org/10.1038/nri.2016.90.

53. Kohio HP, Ajoge HO, Coleman MD, Ndashimye E, Gibson RM, Arts EJ, et al. Specialized DNA structures act as genomic beacons for integration by evolutionarily diverse retroviruses. bioRxiv. 2020;269:25031.

54. Falcinelli SD, Ceriani C, Margolis DM, Archin NM. New frontiers in measuring and characterizing the HIV reservoir. Front Microbiol. 2019;10:117. https://doi.org/10.3389/fmicb.2019.02878.

55. Bruner KM, Murray AJ, Pollack RA, Soliman MG, Laskey SB, Capoferri AA, et al. Defective proviruses rapidly accumulate during acute HIV-1 infection. Nat Med. 2016;22:1043-9. https://doi.org/10.1038/nm.4156.

56. Bruner KM, Wang Z, Simonetti FR, Bender AM, Kwon KJ, Sengupta S, et al. A quantitative approach for measuring the reservoir of latent HIV-1 proviruses. Nature. 2019;566:120-5. https://doi.org/10.1038/ s41586-019-0898-8.

57. Kwon KJ, Timmons AE, Sengupta S, Simonetti FR, Zhang H, Hoh R, et al. Different human resting memory $\mathrm{CD}^{+} \mathrm{T}$ cell subsets show similar low inducibility of latent HIV-1 proviruses. Sci Transl Med. 2020;12: eaax6795. https://doi.org/10.1126/scitranslmed.aax6795.

58. Ho YC, Shan L, Hosmane NN, Wang J, Laskey SB, Rosenbloom DIS, et al. Replication-competent noninduced proviruses in the latent reservoir increase barrier to HIV-1 cure. Cell. 2013;155:540-51. https://doi.org/10. 1016/j.cell.2013.09.020.

59. Antar AAR, Jenike KM, Jang S, Rigau DN, Reeves DB, Hoh R, et al. Longitudinal study reveals HIV-1-infected $\mathrm{CD}^{+} \mathrm{T}$ cell dynamics during long-term antiretroviral therapy. J Clin Invest. 2020;130:3543-59. 
60. Wong JK, Hezareh M, Günthard HF, Havlir DV, Ignacio CC, Spina CA, et al. Recovery of replication-competent HIV despite prolonged suppression of plasma viremia. Science. 1997;278:1291-5.

61. Siliciano JD, Siliciano RF. Enhanced culture assay for detection and quantitation of latently infected, resting $\mathrm{CD}^{+}{ }^{+} \mathrm{T}$-cells carrying replication-competent virus in HIV-1-infected individuals. In: Human retrovirus protocols. 2005. p. 003-16. https://doi.org/10.1385/1-59259-907-9:003.

62. Crooks AM, Bateson R, Cope AB, Dahl NP, Griggs MK, Kuruc JD, et al. Precise quantitation of the latent HIV-1 reservoir: implications for eradication strategies. J Infect Dis. 2015;212:1361-5.

63. Siliciano JD, Kajdas J, Finzi D, Quinn TC, Chadwick K, Margolick JB, et al. Long-term follow-up studies confirm the stability of the latent reservoir for HIV-1 in resting CD4 ${ }^{+}$T cells. Nat Med. 2003;9:727-8.

64. Fourati S, Flandre P, Calin R, Carcelain G, Soulie C, Lambert-Niclot $S$, et al. Factors associated with a low HIV reservoir in patients with prolonged suppressive antiretroviral therapy. J Antimicrob Chemother. 2014;69:753-6. https://doi.org/10.1093/jac/dkt428.

65. Cuzin L, Pugliese P, Sauné K, Allavena C, Ghosn J, Cottalorda J, et al. Levels of intracellular HIV-DNA in patients with suppressive antiretroviral therapy. AIDS. 2015;29:1665-71. https://doi.org/10.1097/QAD.00000 00000000723

66. Nyabuti MN, Petersen ML, Bukusi EA, Kamya MR, Mwangwa F, Kabami J, et al. Characteristics of HIV seroconverters in the setting of universal test and treat: results from the SEARCH trial in rural Uganda and Kenya. PLoS ONE. 2021;16: e0243167. https://doi.org/10.1371/journal.pone. 0243167.

67. Vatakis DN, Nixon CC, Zack JA. Quiescent T cells and HIV: an unresolved relationship. Immunol Res. 2010;48:110-21. https://doi.org/10.1007/ s12026-010-8171-0.

68. Wei X, Ghosh SK, Taylor ME, Johnson VA, Emini EA, Deutsch P, et al. Viral dynamics in human immunodeficiency virus type 1 infection. Nature. 1995;373:117-22. https://doi.org/10.1038/373117a0.

69. Ho DD, Neumann AU, Perelson AS, Chen W, Leonard JM, Markowitz M. Rapid turnover of plasma virions and CD4 lymphocytes in HIV-1 infection. Nature. 1995;373:123-6. https://doi.org/10.1038/373123a0.

70. Shan L, Deng K, Gao H, Xing S, Capoferri AA, Durand CM, et al. Transcriptional reprogramming during effector-to-memory transition renders $\mathrm{CD}^{+}{ }^{+} \mathrm{T}$ cells permissive for latent HIV-1 infection. Immunity. 2017;47:766-775.e3. https://doi.org/10.1016/j.immuni.2017.09.014

71. Dai J, Agosto LM, Baytop C, Yu JJ, Pace MJ, Liszewski MK, et al. Human immunodeficiency virus integrates directly into naïve resting $C D 4^{+}$ T cells but enters naïve cells less efficiently than memory cells. J Virol. 2009;83:4528-37. https://doi.org/10.1128/JVI.01910-08.

72. Agosto LM, Yu JJ, Dai J, Kaletsky R, Monie D, O'Doherty U. HIV-1 integrates into resting $C D 4^{+} T$ cells even at low inoculums as demonstrated with an improved assay for HIV-1 integration. Virology. 2007;368:60-72. https://doi.org/10.1016/j.virol.2007.06.001.

73. Stevenson M, Stanwick TL, Dempsey MP, Lamonica CA. HIV-1 replication is controlled at the level of T cell activation and proviral integration. EMBO J. 1990;9:1551-60. https://doi.org/10.1002/j.1460-2075.1990. tb08274.x.

74. Zack JA, Arrigo SJ, Weitsman SR, Go AS, Haislip A, Chen ISY. HIV-1 entry into quiescent primary lymphocytes: molecular analysis reveals a labile, latent viral structure. Cell. 1990;61:213-22. https://doi.org/10.1016/ 0092-8674(90)90802-L.

75. Salazar-Gonzalez JF, Bailes E, Pham KT, Salazar MG, Guffey MB, Keele BF, et al. Deciphering human immunodeficiency virus type 1 transmission and early envelope diversification by single-genome amplification and sequencing. J Virol. 2008;82:3952-70. https://doi.org/10.1128/JVI. 02660-07.

76. Abrahams M-R, Anderson JA, Giorgi EE, Seoighe C, Mlisana K, Ping L-H, et al. Quantitating the multiplicity of infection with human immunodeficiency virus type 1 subtype $C$ reveals a non-poisson distribution of transmitted variants. J Virol. 2009;83:3556-67. https://doi.org/10.1128/ JVI.02132-08.

77. Kearney M, Maldarelli F, Shao W, Margolick JB, Daar ES, Mellors JW, et al. Human immunodeficiency virus type 1 population genetics and adaptation in newly infected individuals. J Virol. 2009;83:2715-27. https://doi. org/10.1128/JVI.01960-08.

78. Treurnicht FK, Seoighe C, Martin DP, Wood N, Abrahams M-R, de Assis Rosa D, et al. Adaptive changes in HIV-1 subtype C proteins during early infection are driven by changes in HLA-associated immune pressure. Virology. 2010;396:213-25. https://doi.org/10.1016/j.virol.2009.10.002.

79. Abrahams M-R, Treurnicht FK, Ngandu NK, Goodier SA, Marais JC, Bredell $\mathrm{H}$, et al. Rapid, complex adaptation of transmitted HIV-1 full-length genomes in subtype C-infected individuals with differing disease progression. AIDS. 2013;27:507-18. https://doi.org/10.1097/QAD.0b013 e32835cab64.

80. Maldarelli F, Kearney M, Palmer S, Stephens R, Mican J, Polis MA, et al. HIV populations are large and accumulate high genetic diversity in a nonlinear fashion. JVirol. 2013;87:10313-23. https://doi.org/10.1128/JVI. 01225-12.

81. Brodin J, Zanini F, Thebo L, Lanz C, Bratt G, Neher RA, et al. Establishment and stability of the latent HIV-1 DNA reservoir. Elife. 2016. https:// doi.org/10.7554/eLife.18889.

82. Pankau MD, Reeves DB, Harkins E, Ronen K, Jaoko W, Mandaliya K, et al. Dynamics of HIV DNA reservoir seeding in a cohort of superinfected Kenyan women. PLoS Pathog. 2020;16: e1008286. https://doi.org/10. 1371/journal.ppat.1008286.

83. Jones BR, Kinloch NN, Horacsek J, Ganase B, Harris M, Harrigan PR, et al. Phylogenetic approach to recover integration dates of latent HIV sequences within-host. Proc Natl Acad Sci. 2018;115:E8958-67. https:// doi.org/10.1073/pnas.1802028115.

84. Jones BR, Miller RL, Kinloch NN, Tsai O, Rigsby H, Sudderuddin H, et al. Genetic diversity, compartmentalization, and age of hiv proviruses persisting in $\mathrm{CD}^{+} \mathrm{T}$ cell subsets during long-term combination antiretroviral therapy. J Virol. 2020;94:1786-805. https://doi.org/10.1128/JVI. 01786-19.

85. Lee GQ, Reddy K, Einkauf KB, Gounder K, Chevalier JM, Dong KL, et al. HIV-1 DNA sequence diversity and evolution during acute subtype C infection. Nat Commun. 2019;10(1):1-11.

86. Chomont N, El-Far M, Ancuta P, Trautmann L, Procopio FA, Yassine-Diab $B$, et al. HIV reservoir size and persistence are driven by $T$ cell survival and homeostatic proliferation. Nat Med. 2009;15:893-900. https://doi. org/10.1038/nm.1972.

87. Soriano-Sarabia N, Bateson RE, Dahl NP, Crooks AM, Kuruc JD, Margolis DM, et al. Quantitation of replication-competent HIV-1 in populations of resting CD4 ${ }^{+}$T cells. J Virol. 2014;88:14070-7. https://doi.org/10. 1128/JVI.01900-14.

88. Hiener B, Horsburgh BA, Eden J-S, Barton K, Schlub TE, Lee E, et al. Identification of genetically intact hiv-1 proviruses in specific $\mathrm{CD}^{+}{ }^{+} \mathrm{T}$ cells from effectively treated participants. Cell Rep. 2017;21:813-22. https:// doi.org/10.1016/j.celrep.2017.09.081.

89. Buzon MJ, Sun H, Li C, Shaw A, Seiss K, Ouyang Z, et al. HIV-1 persistence in $\mathrm{CD}^{+}{ }^{+} \mathrm{T}$ cells with stem cell-like properties. Nat Med. 2014;20:139-42.

90. Jaafoura S, de Herve MDG, Hernandez-Vargas EA, Hendel-Chavez H, Abdoh M, Mateo MC, et al. Progressive contraction of the latent HIV reservoir around a core of less-differentiated $C D 4^{+}$memory $T$ Cells. Nat Commun. 2014;5:5407. https://doi.org/10.1038/ncomms6407.

91. Buzon MJ, Martin-Gayo E, Pereyra F, Ouyang Z, Sun H, Li JZ, et al. Long-term antiretroviral treatment initiated at primary HIV-1 infection affects the size, composition, and decay kinetics of the reservoir of HIV-1-infected CD4 T cells. J Virol. 2014;88:10056-65. https://doi.org/10. 1128/JVI.01046-14.

92. De Scheerder MA, Vrancken B, Dellicour S, Schlub T, Lee E, Shao W, et al. HIV rebound is predominantly fueled by genetically identical viral expansions from diverse reservoirs. Cell Host Microbe. 2019;26(3):347358.e7.

93. Rothenberger MK, Keele BF, Wietgrefe SW, Fletcher CV, Beilman GJ, Chipman JG, et al. Large number of rebounding/founder HIV variants emerge from multifocal infection in lymphatic tissues after treatment interruption. Proc Natl Acad Sci. 2015;112:E1126-34. https://doi.org/10. 1073/pnas.1414926112.

94. Chaillon A, Gianella S, Dellicour S, Rawlings SA, Schlub TE, De Oliveira MF, et al. HIV persists throughout deep tissues with repopulation from multiple anatomical sources. J Clin Invest. 2020;130:1699-712. https:// doi.org/10.1172/JCl134815.

95. Rosenbloom DIS, Hill AL, Laskey SB, Siliciano RF. Re-evaluating evolution in the HIV reservoir. Nature. 2017;551:E6-9. https://doi.org/10.1038/ nature24634. 
96. Lorenzi JCC, Cohen YZ, Cohn LB, Kreider EF, Barton JP, Learn GH, et al. Paired quantitative and qualitative assessment of the replication-competent HIV-1 reservoir and comparison with integrated proviral DNA. Proc Natl Acad Sci. 2016;113:E7908-16. https://doi.org/10.1073/pnas. 1617789113.

97. Hosmane NN, Kwon KJ, Bruner KM, Capoferri AA, Beg S, Rosenbloom DIS, et al. Proliferation of latently infected CD4 + T cells carrying replication-competent HIV-1: potential role in latent reservoir dynamics. J Exp Med. 2017;214:959-72. https://doi.org/10.1084/jem.20170193.

98. Simonetti FR, Sobolewski MD, Fyne E, Shao W, Spindler J, Hattori J, et al. Clonally expanded CD4 ${ }^{+} \mathrm{T}$ cells can produce infectious HIV-1 in vivo. Proc Natl Acad Sci. 2016;113:1883-8. https://doi.org/10.1073/pnas. 1522675113.

99. Bui JK, Sobolewski MD, Keele BF, Spindler J, Musick A, Wiegand A, et al. Proviruses with identical sequences comprise a large fraction of the replication-competent HIV reservoir. PLoS Pathog. 2017;13: e1006283. https://doi.org/10.1371/journal.ppat.1006283.

100. Wagner TA, McKernan JL, Tobin NH, Tapia KA, Mullins JI, Frenkel LM. An increasing proportion of monotypic HIV-1 DNA sequences during antiretroviral treatment suggests proliferation of HIV-infected cells. J Virol. 2013;87:1770-8. https://doi.org/10.1128/JVI.01985-12.

101. Cohn LB, da Silva IT, Valieris R, Huang AS, Lorenzi JCC, Cohen YZ, et al. Clonal $\mathrm{CD} 4^{+} \mathrm{T}$ cells in the HIV-1 latent reservoir display a distinct gene profile upon reactivation. Nat Med. 2018;24:604-9. https://doi.org/10. 1038/s41591-018-0017-7.

102. Kearney MF, Wiegand A, Shao W, Coffin JM, Mellors JW, Lederman M, et al. Origin of rebound plasma HIV includes cells with identical proviruses that are transcriptionally active before stopping of antiretroviral therapy. JVirol. 2016;90:1369-76. https://doi.org/10.1128/JVI.02139-15.

103. Boritz EA, Darko S, Swaszek L, Wolf G, Wells D, Wu X, et al. Multiple origins of virus persistence during natural control of HIV infection. Cell. 2016. https://doi.org/10.1016/j.cell.2016.06.039

104. Cohn LB, Silva IT, Oliveira TY, Rosales RA, Parrish EH, Learn GH, et al. HIV-1 integration landscape during latent and active infection. Cell. 2015;160:420-32. https://doi.org/10.1016/..cell.2015.01.020.

105. Lee GQ, Kuo H-H, Yu XG, Lichterfeld M, Orlova-Fink N, Einkauf K, et al. Clonal expansion of genome-intact HIV-1 in functionally polarized Th1 CD4+ T cells. J Clin Invest. 2017:127:2689-96.

106. Anderson EM, Maldarelli F. The role of integration and clonal expansion in HIV infection: live long and prosper. Retrovirology. 2018;15:71. https://doi.org/10.1186/s12977-018-0448-8.

107. Mbonye U, Karn J. The molecular basis for human immunodeficiency virus latency. Annu Rev Virol. 2017;4:261-85. https://doi.org/10.1146/ annurev-virology-101416-041646.

108. Dahabieh MS, Ooms M, Simon V, Sadowski I. A doubly fluorescent HIV-1 reporter shows that the majority of integrated HIV-1 is latent shortly after infection. JVirol. 2013;87:4716-27. https://doi.org/10.1128/JVl. 03478-12.

109. Chakraborty S, Kabi M, Ranga U. A Stronger transcription regulatory circuit of HIV-1C drives the rapid establishment of latency with implications for the direct involvement of Tat. J Virol. 2020. https://doi.org/10. 1128/JVI.00503-20.

110. Duverger A, Wolschendorf F, Zhang M, Wagner F, Hatcher B, Jones J, et al. An AP-1 binding site in the enhancer/core element of the HIV-1 promoter controls the ability of HIV-1 to establish latent infection. J Virol. 2013;87:2264-77. https://doi.org/10.1128/JVI.01594-12.

111. van der Sluis RM, Derking R, Breidel S, Speijer D, Berkhout B, Jeeninga RE. Interplay between viral Tat protein and c-Jun transcription factor in controlling LTR promoter activity in different human immunodeficiency virus type I subtypes. J Gen Virol. 2014;95:968-79. https://doi.org/10. 1099/vir.0.059642-0.

112. Razooky BS, Pai A, Aull K, Rouzine IM, Weinberger LS. A hardwired HIV latency program. Cell. 2015;160:990-1001. https://doi.org/10.1016/j.cell. 2015.02.009.

113. Lassen KG, Ramyar KX, Bailey JR, Zhou Y, Siliciano RF. Nuclear retention of multiply spliced HIV-1 RNA in resting CD4 ${ }^{+} \mathrm{T}$ cells. PLoS Pathog. 2006;2: e68. https://doi.org/10.1371/journal.ppat.0020068.

114. Kurosu T, Mukai T, Komoto S, Ibrahim MS, Li Y, Kobayashi T, et al. Human immunodeficiency virus type 1 subtype $C$ exhibits higher transactivation activity of Tat than subtypes B and E. Microbiol Immunol. 2002;46:787-99. https://doi.org/10.1111/j.1348-0421.2002.tb02766.x.
115. Spector C, Mele AR, Wigdahl B, Nonnemacher MR. Genetic variation and function of the HIV-1 Tat protein. Med Microbiol Immunol. 2019;208:131-69. https://doi.org/10.1007/s00430-019-00583-z.

116. Singh S, Kumar A, Brijwal M, Choudhary A, Singh K, Singh R, et al. IntraClade $C$ signature polymorphisms in HIV-1 LTR region: the Indian and African lookout. Virus Res. 2021;297: 198370. https://doi.org/10.1016/j. virusres.2021.198370.

117. Rossenkhan R, MacLeod IJ, Sebunya TK, Castro-Nallar E, McLane MF, Musonda R, et al. tat exon 1 exhibits functional diversity during HIV-1 subtype C primary infection. JVirol. 2013;87:5732-45. https://doi.org/ 10.1128/JVI.03297-12.

118. de Almeida SM, Rotta I, Vidal LRR, dos Santos JS, Nath A, Johnson $\mathrm{K}$, et al. HIV-1C and HIV-1B Tat protein polymorphism in Southern Brazil. J Neurovirol. 2021;27:126-36. https://doi.org/10.1007/ s13365-020-00935-Z.

119. Triboulet R, Mari B, Lin Y-L, Chable-Bessia C, Bennasser Y, Lebrigand K, et al. Suppression of MicroRNA-silencing pathway by HIV-1 during virus replication. Science. 2007;315:1579-82. https://doi.org/10.1126/science. 1136319.

120. de Vries W, Berkhout B. RNAi suppressors encoded by pathogenic human viruses. Int J Biochem Cell Biol. 2008;40:2007-12. https://doi. org/10.1016/.biocel.2008.04.015.

121. Bennasser Y, Le S-Y, Benkirane M, Jeang K-T. Evidence that HIV-1 encodes an siRNA and a suppressor of RNA silencing. Immunity. 2005;22:607-19. https://doi.org/10.1016/j.immuni.2005.03.010.

122. Qian S, Zhong X, Yu L, Ding B, de Haan P, Boris-Lawrie K. HIV-1 Tat RNA silencing suppressor activity is conserved across kingdoms and counteracts translational repression of HIV-1. Proc Natl Acad Sci. 2009:106:605-10. https://doi.org/10.1073/pnas.0806822106.

123. Ronsard L, Yousif AS, Ramesh J, Sumi N, Gorman M, Ramachandran VG, et al. In-vitro subtype-specific modulation of HIV-1 trans-activator of transcription (tat) on rnai silencing suppressor activity and cell death. Viruses. 2019. https://doi.org/10.3390/v11110976.

124. Buffalo CZ, Iwamoto Y, Hurley JH, Ren X. How HIV Nef proteins hijack membrane traffic to promote infection. JVirol. 2019. https://doi.org/10. 1128/JVI.01322-19.

125. Schwartz O, Maréchal V, Le GS, Lemonnier F, Heard J-M. Endocytosis of major histocompatibility complex class I molecules is induced by the HIV-1 Nef protein. Nat Med. 1996;2:338-42. https://doi.org/10.1038/ nm0396-338.

126. Collins KL, Chen BK, Kalams SA, Walker BD, Baltimore D. HIV-1 Nef protein protects infected primary cells against killing by cytotoxic $T$ lymphocytes. Nature. 1998;391:397-401. https://doi.org/10.1038/34929.

127. Omondi FH, Chandrarathna S, Mujib S, Brumme CJ, Jin SW, Sudderuddin $\mathrm{H}$, et al. HIV subtype and Nef-mediated immune evasion function correlate with viral reservoir size in early-treated individuals. J Virol. 2019. https://doi.org/10.1128/JVI.01832-18.

128. Mann JK, Byakwaga $H$, Kuang XT, Le AQ, Brumme CJ, Mwimanzi P, et al. Ability of HIV-1 Nef to downregulate CD4 and HLA class I differs among viral subtypes. Retrovirology. 2013;10:100. https://doi.org/10.1186/ 1742-4690-10-100.

129. Henrich TJ, Gandhi RT. Early treatment and HIV-1 reservoirs: a stitch in time? J Infect Dis. 2013;208:1189-93. https://doi.org/10.1093/infdis/ jit307.

130. Hocqueloux L, Avettand-Fènoël V, Jacquot S, PrazuckT, Legac E, Mélard A, et al. Long-term antiretroviral therapy initiated during primary HIV-1 infection is key to achieving both low HIV reservoirs and normal T cell counts. J Antimicrob Chemother. 2013;68:1169-78. https://doi.org/10. 1093/jac/dks533.

131. Ananworanich J, Schuetz A, Vandergeeten C, Sereti I, de Souza M, Rerknimitr R, et al. Impact of multi-targeted antiretroviral treatment on gut T cell depletion and HIV reservoir seeding during acute HIV infection. PLoS ONE. 2012;7: e33948. https://doi.org/10.1371/journal.pone. 0033948.

132. Archin NM, Vaidya NK, Kuruc JAD, Liberty AL, Wiegand A, Kearney MF, et al. Immediate antiviral therapy appears to restrict resting CD4 + cell HIV-1 infection without accelerating the decay of latent infection. Proc Natl Acad Sci. 2012;109:9523-8.

133. Boulassel M-R, Chomont N, Pai NP, Gilmore N, Sékaly R-P, Routy J-P. CD4 T cell nadir independently predicts the magnitude of the HIV 
reservoir after prolonged suppressive antiretroviral therapy. J Clin Virol. 2012;53:29-32. https://doi.org/10.1016/j.jcv.2011.09.018.

134. Martin GE, Pace M, Shearer FM, Zilber E, Hurst J, Meyerowitz J, et al. Levels of human immunodeficiency virus dna are determined before art initiation and linked to CD8 T-cell activation and memory expansion. J Infect Dis. 2020;221:1135-45. https://doi.org/10.1093/infdis/jiz563.

135. Roberts L, Passmore J-AS, Mlisana K, Williamson C, Little F, Bebell LM et al. Genital tract inflammation during early HIV-1 infection predicts higher plasma viral load set point in women. J Infect Dis. 2012;205:194203. https://doi.org/10.1093/infdis/jir715.

136. Langford SE, Ananworanich J, Cooper DA. Predictors of disease progression in HIV infection: a review. AIDS Res Ther. 2007;4:11. https://doi.org/ 10.1186/1742-6405-4-11.

137. Claiborne DT, Prince JL, Scully E, Macharia G, Micci L, Lawson B, et al. Replicative fitness of transmitted HIV-1 drives acute immune activation, proviral load in memory $\mathrm{CD}^{+} \mathrm{T}$ cells, and disease progression. Proc Natl Acad Sci. 2015. https://doi.org/10.1073/pnas.1421607112.

138. Wilson EM, Sereti I. Immune restoration after antiretroviral therapy: the pitfalls of hasty or incomplete repairs. Immunol Rev. 2013;254:343-54. https://doi.org/10.1111/imr.12064.

139. Koesters SA, Matu L, Kiama P, Anzala O, Embree J, Plummer FA, et al. Elevation of immune activation in kenyan women is associated with alterations in immune function: implications for vaccine development. J Clin Immunol. 2004;24:702-9. https://doi.org/10.1007/ s10875-004-6238-1.

140. Kalinkovich A, Borkow G, Weisman Z, Tsimanis A, Stein M, Bentwich Z. Increased CCR5 and CXCR4 expression in Ethiopians living in Israel: environmental and constitutive factors. Clin Immunol. 2001;100:107-17. https://doi.org/10.1006/clim.2001.5040.

141. Messele T, Abdulkadir M, Fontanet AL, Petros B, Hamann D, Koot M, et al. Reduced naive and increased activated CD4 and CD8 cells in healthy adult Ethiopians compared with their Dutch counterparts. Clin Exp Immunol. 1999;115:443-50. https://doi.org/10.1046/j.1365-2249. 1999.00815.x.

142. Rizzardini G, Piconi S, Ruzzante S, Fusi M, Lukwiya M, Declich S, et al. Immunological activation markers in the serum of African and European HIV-seropositive and seronegative individuals. AIDS. 1996;10:15351542.

143. Rizzardini G, Trabattoni D, Saresella M, Piconi S, Lukwiya M, Declich S, et al. Immune activation in HIV-infected African individuals. ItalianUgandan AIDS cooperation program. AIDS. 1998;12:2387-96.

144. Roberts L, Passmore JS, Williamson C, Bebell LM, Mlisana K, Burgers WA, et al. Plasma cytokine levels during acute HIV-1 infection predict HIV disease progression. AIDS. 2010;24:819-31.

145. Margolis DM, Archin NM, Cohen MS, Eron JJ, Ferrari G, Garcia JV, et al. Curing HIV: Seeking to target and clear persistent infection. Cell. 2020;181:189-206. https://doi.org/10.1016/j.cell.2020.03.005.

146. Churchill MJ, Deeks SG, Margolis DM, Siliciano RF, Swanstrom R. HIV reservoirs: what, where and how to target them. Nat Rev Microbiol. 2015;14:55-60. https://doi.org/10.1038/nrmicro.2015.5.

147. Deeks SG, Lewin SR, Ross AL, Ananworanich J, Benkirane M, Cannon P, et al. International AIDS Society global scientific strategy: towards an HIV cure 2016. Nat Med. 2016;22:839-50. https://doi.org/10.1038/nm. 4108.

148. Poon AFY, Prodger JL, Lynch BA, Lai J, Reynolds SJ, Kasule J, et al. Quantitation of the latent HIV-1 reservoir from the sequence diversity in viral outgrowth assays. Retrovirology. 2018;15:47. https://doi.org/10.1186/ s12977-018-0426-1.

149. Gupta RK, Abdul-Jawad S, McCoy LE, Mok HP, Peppa D, Salgado M, et al. HIV-1 remission following CCR5 $\triangle 32 / \triangle 32$ haematopoietic stem-cell transplantation. Nature. 2019;568:244-8. https://doi.org/10.1038/ s41586-019-1027-4.

150. Hütter G, Nowak D, Mossner M, Ganepola S, Müßig A, Allers K, et al. Long-term control of HIV by CCR5 Delta32/Delta32 stem-cell transplantation. N Engl J Med. 2009;360:692-8. https://doi.org/10.1056/NEJMo a0802905.

151. Kim Y, Anderson JL, Lewin SR. Getting the "kill" into "shock and kill": strategies to eliminate latent HIV. Cell Host Microbe. 2018;23:14-26. https:// doi.org/10.1016/j.chom.2017.12.004.

152. Pinkevych M, Cromer D, Tolstrup M, Grimm AJ, Cooper DA, Lewin SR, et al. HIV reactivation from latency after treatment interruption occurs on average every 5-8 days -implications for HIV remission. PLoS Pathog. 2015;11: e1005000. https://doi.org/10.1371/journal.ppat.10050 00 .

153. Davenport MP, Khoury DS, Cromer D, Lewin SR, Kelleher AD, Kent SJ. Functional cure of HIV: the scale of the challenge. Nat Rev Immunol. 2019;19:45-54. https://doi.org/10.1038/s41577-018-0085-4.

154. Spina CA, Anderson J, Archin NM, Bosque A, Chan J, Famiglietti M, et al. An in-depth comparison of latent HIV-1 reactivation in multiple cell model systems and resting $\mathrm{CD}^{+} \mathrm{T}$ cells from aviremic patients. PLoS Pathog. 2013;9: e1003834. https://doi.org/10.1371/journal.ppat.10038 34.

155. Søgaard OS, Graversen ME, Leth S, Olesen R, Brinkmann CR, Nissen SK, et al. The depsipeptide romidepsin reverses HIV-1 latency in vivo. PLoS Pathog. 2015;11: e1005142. https://doi.org/10.1371/journal.ppat.10051 42.

156. Rasmussen TA, Tolstrup M, Brinkmann CR, Olesen R, Erikstrup C, Solomon A, et al. Panobinostat, a histone deacetylase inhibitor, for latentvirus reactivation in HIV-infected patients on suppressive antiretroviral therapy: a phase 1/2, single group, clinical trial. Lancet HIV. 2014;1:e1321. https://doi.org/10.1016/S2352-3018(14)70014-1.

157. Archin NM, Kirchherr JL, Sung JAM, Clutton G, Sholtis K, Xu Y, et al. Interval dosing with the HDAC inhibitor vorinostat effectively reverses HIV latency. J Clin Invest. 2017;127:3126-35. https://doi.org/10.1172/ JCl92684.

158. Gutiérrez C, Serrano-Villar S, Madrid-Elena N, Pérez-Elías MJ, Martín ME, Barbas C, et al. Bryostatin-1 for latent virus reactivation in HIV-infected patients on antiretroviral therapy. AIDS. 2016;30:1385-92. https://doi. org/10.1097/QAD.0000000000001064.

159. Schiavoni G, Mattei F, Gabriele L. Type I interferons as stimulators of DC-mediated cross-priming: impact on anti-tumor response. Front Immunol. 2013. https://doi.org/10.3389/fimmu.2013.00483.

160. Menne S, Tumas DB, Liu KH, Thampi L, AlDeghaither D, Baldwin BH, et al. Sustained efficacy and seroconversion with the Toll-like receptor 7 agonist GS-9620 in the Woodchuck model of chronic hepatitis B. J Hepatol. 2015;62:1237-45. https://doi.org/10.1016/j.jhep.2014.12.026.

161. Lanford RE, Guerra B, Chavez D, Giavedoni L, Hodara VL, Brasky KM, et al. GS-9620, an oral agonist of toll-like receptor-7, induces prolonged suppression of hepatitis B virus in chronically infected chimpanzees. Gastroenterology. 2013;144:1508-1517.e10. https://doi.org/10.1053/j. gastro.2013.02.003.

162. Tsai A, Irrinki A, Kaur J, Cihlar T, Kukolj G, Sloan DD, et al. Toll-like receptor 7 agonist GS-9620 induces HIV expression and HIV-specific immunity in cells from HIV-infected individuals on suppressive antiretroviral therapy. J Virol. 2017. https://doi.org/10.1128/JVI.02166-16.

163. Riddler SA, Para M, Benson CA, Mills A, Ramgopal M, DeJesus E, et al. Vesatolimod, a toll-like receptor 7 agonist, induces immune activation in virally suppressed adults living with human immunodeficiency virus-1. Clin Infect Dis. 2020. https://doi.org/10.1093/cid/ciaa1534.

164. Kim YK, Mbonye U, Hokello J, Karn J. T-cell receptor signaling enhances transcriptional elongation from latent HIV proviruses by activating P-TEFb through an ERK-dependent pathway. J Mol Biol. 2011;410:896916. https://doi.org/10.1016/j.jmb.2011.03.054.

165. Mohammadi P, di lulio J, Muñoz M, Martinez R, Bartha I, Cavassini M, et al. Dynamics of HIV latency and reactivation in a primary $\mathrm{CD}^{+} \mathrm{T}$ Cell model. PLoS Pathog. 2014;10: e1004156. https://doi.org/10.1371/journ al.ppat.1004156.

166. Williams SA, Greene WC. Regulation of HIV-1 latency by T-cell activation. Cytokine. 2007;39:63-74. https://doi.org/10.1016/j.cyto.2007.05.017.

167. Shete A, Thakar M, Singh DP, Gangakhedkar R, Gaikwad A, Pawar J, et al. HIV antigen-specific reactivation of HIV infection from cellular reservoirs: implications in the settings of therapeutic vaccinations. AIDS Res Hum Retroviruses. 2012;28:835-43. https://doi.org/10.1089/aid.2010. 0363.

168. Douek DC, Brenchley JM, Betts MR, Ambrozak DR, Hill BJ, Okamoto Y, et al. HIV preferentially infects HIV-specific $\mathrm{CD}^{+}{ }^{+} \mathrm{T}$ cells. Nature. 2002:417:95-8. https://doi.org/10.1038/417095a.

169. Mann JFS, Pankrac J, Klein K, McKay PF, King DFL, Gibson R, et al. A targeted reactivation of latent HIV-1 using an activator vector in patient samples from acute infection. EBioMedicine. 2020;59: 102853. https:// doi.org/10.1016/j.ebiom.2020.102853. 
170. Pankrac J, Klein K, McKay PF, King DFL, Bain K, Knapp J, et al. A heterogeneous human immunodeficiency virus-like particle (VLP) formulation produced by a novel vector system. Vaccines. 2018;3:2. https://doi.org/ 10.1038/s41541-017-0040-6.

171. Suzuki K, Ahlenstiel C, Marks K, Kelleher AD. Promoter targeting RNAs: Unexpected contributors to the control of HIV-1 transcription. Mol Ther Nucleic Acids. 2015;4: e222. https://doi.org/10.1038/mtna.2014.67.

172. Suzuki K, Hattori S, Marks K, Ahlenstiel C, Maeda Y, Ishida T, et al. Promoter targeting shRNA suppresses HIV-1 infection in vivo through transcriptional gene silencing. Mol Ther Nucleic Acids. 2013;2: e137. https://doi.org/10.1038/mtna.2013.64.

173. Méndez C, Ledger S, Petoumenos K, Ahlenstiel C, Kelleher AD. RNAinduced epigenetic silencing inhibits HIV-1 reactivation from latency. Retrovirology. 2018;15:67. https://doi.org/10.1186/s12977-018-0451-0.

174. Mousseau G, Clementz MA, Bakeman WN, Nagarsheth N, Cameron $M$, Shi J, et al. An analog of the natural steroidal alkaloid cortistatin a potently suppresses Tat-dependent HIV transcription. Cell Host Microbe. 2012;12:97-108. https://doi.org/10.1016/j.chom.2012.05.016.

175. Mousseau G, Kessing CF, Fromentin R, Trautmann L, Chomont N, Valente ST. The Tat inhibitor didehydro-cortistatin A prevents HIV-1 Reactivation from latency. MBio. 2015. https://doi.org/10.1128/mBio. 00465-15.

176. Lalonde MS, Lobritz MA, Ratcliff A, Chamanian M, Athanassiou Z, Tyagi $M$, et al. Inhibition of both HIV-1 reverse transcription and gene expression by a cyclic peptide that binds the tat-transactivating response element (TAR) RNA. PLoS Pathog. 2011;7: e1002038. https://doi.org/10. 1371/journal.ppat.1002038.

177. Shortridge MD, Wille PT, Jones AN, Davidson A, Bogdanovic J, Arts E, et al. An ultra-high affinity ligand of HIV-1 TAR reveals the RNA structure recognized by P-TEFb. Nucleic Acids Res. 2019;47:1523-31. https://doi. org/10.1093/nar/gky1197.

178. Tolley EE, Zangeneh SZ, Chau G, Eron J, Grinsztejn B, Humphries H, et al. Acceptability of long-acting injectable cabotegravir (CAB LA) in HIV-uninfected individuals: HPTN 077. AIDS Behav. 2020;24:2520-31. https://doi.org/10.1007/s10461-020-02808-2.

179. Chun T-W, Carruth L, Finzi D, Shen X, DiGiuseppe JA, Taylor H, et al. Quantification of latent tissue reservoirs and total body viral load in HIV-1 infection. Nature. 1997;387:183-8. https://doi.org/10.1038/38718 $3 \mathrm{a} 0$.

180. Strain MC, Lada SM, Luong T, Rought SE, Gianella S, Terry VH, et al. Highly precise measurement of HIV DNA by droplet digital PCR. PLoS ONE. 2013;8: e55943. https://doi.org/10.1371/journal.pone.0055943.

181. Gaebler C, Lorenzi JCC, Oliveira TY, Nogueira L, Ramos V, Lu C-L, et al. Combination of quadruplex $\mathrm{PPCR}$ and next-generation sequencing for qualitative and quantitative analysis of the HIV-1 latent reservoir. J Exp Med. 2019;216:2253-64. https://doi.org/10.1084/jem.20190896.

182. Chun TW, Finzi D, Margolick J, Chadwick K, Schwartz D, Siliciano RF. In vivo fate of HIV-1-infected T cells: quantitative analysis of the transition to stable latency. Nat Med. 1995:1:1284-90.
183. Archin NM, Liberty AL, Kashuba AD, Choudhary SK, Kuruc JD, Crooks AM, et al. Administration of vorinostat disrupts HIV-1 latency in patients on antiretroviral therapy. Nature. 2012;487:482-5. https://doi.org/10. 1038/nature11286.

184. Pasternak AO, Lukashov WV, Berkhout B. Cell-associated HIV RNA: a dynamic biomarker of viral persistence. Retrovirology. 2013;10:41. https://doi.org/10.1186/1742-4690-10-41.

185. Procopio FA, Fromentin R, Kulpa DA, Brehm JH, Bebin A-G, Strain MC, et al. A novel assay to measure the magnitude of the inducible viral reservoir in HIV-infected individuals. EBioMedicine. 2015;2:874-83. https:// doi.org/10.1016/j.ebiom.2015.06.019.

186. Spivak AM, Bosque A, Balch AH, Smyth D, Martins L, Planelles V. Ex vivo bioactivity and HIV-1 latency reversal by ingenol dibenzoate and panobinostat in resting $\mathrm{CD} 4^{+} \mathrm{T}$ cells from aviremic patients. Antimicrob Agents Chemother. 2015;59:5984-91. https://doi.org/10.1128/AAC. 01077-15

187. Das B, Dobrowolski C, Luttge B, Valadkhan S, Chomont N, Johnston R, et al. Estrogen receptor-1 is a key regulator of HIV-1 latency that imparts gender-specific restrictions on the latent reservoir. Proc Natl Acad Sci. 2018;115:E7795-804. https://doi.org/10.1073/pnas.1803468115.

188. Pasternak AO, Berkhout B. What do we measure when we measure cell-associated HIV RNA. Retrovirology. 2018;15:1-16. https://doi.org/10. 1186/s12977-018-0397-2

189. Baxter AE, Niessl J, Fromentin R, Richard J, Porichis F, Charlebois R, et al. Single-cell characterization of viral translation-competent reservoirs in HIV-infected individuals. Cell Host Microbe. 2016;20:368-80. https://doi. org/10.1016/j.chom.2016.07.015.

190. Baxter AE, Niessl J, Fromentin R, Richard J, Porichis F, Massanella M, et al. Multiparametric characterization of rare HIV-infected cells using an RNA-flow FISH technique. Nat Protoc. 2017;12:2029-49. https://doi.org/ 10.1038/nprot.2017.079

191. Pardons M, Baxter AE, Massanella M, Pagliuzza A, Fromentin R, Dufour $C$, et al. Single-cell characterization and quantification of translationcompetent viral reservoirs in treated and untreated HIV infection. PLoS Pathog. 2019;15: e1007619. https://doi.org/10.1371/journal.ppat.10076 19.

192. Grau-Expósito J, Serra-Peinado C, Miguel L, Navarro J, Curran A, Burgos $J$, et al. A novel single-cell FISH-Flow assay identifies effector memory $\mathrm{CD}^{+} \mathrm{T}$ cells as a major niche for HIV-1 transcription in HIV-infected patients. MBio. 2017:8:e00876-e917. https://doi.org/10.1128/mBio. 00876-17

\section{Publisher's Note}

Springer Nature remains neutral with regard to jurisdictional claims in published maps and institutional affiliations.
Ready to submit your research? Choose BMC and benefit from:

- fast, convenient online submission

- thorough peer review by experienced researchers in your field

- rapid publication on acceptance

- support for research data, including large and complex data types

- gold Open Access which fosters wider collaboration and increased citations

- maximum visibility for your research: over 100M website views per year

At BMC, research is always in progress.

Learn more biomedcentral.com/submissions 